\title{
Semicontinuous measurements of gas-particle partitioning of organic acids in a ponderosa pine forest using a MOVI-HRToF-CIMS
}

\author{
R. L. N. Yatavelli ${ }^{1,2,3}$, H. Stark ${ }^{2,4}$, S. L. Thompson ${ }^{1,2}$, J. R. Kimmel ${ }^{4,5}$, M. J. Cubison ${ }^{5}$, D. A. Day ${ }^{1,2}$, \\ P. Campuzano-Jost ${ }^{1,2}$, B. B. Palm ${ }^{1,2}$, A. Hodzic ${ }^{6}$, J. A. Thornton ${ }^{7}$, J. T. Jayne ${ }^{4}$, D. R. Worsnop ${ }^{4,8}$, and J. L. Jimenez ${ }^{1,2}$ \\ ${ }^{1}$ Cooperative Institute for Research in Environmental Sciences, University of Colorado, Boulder, CO 80309, USA \\ ${ }^{2}$ Department of Chemistry and Biochemistry, University of Colorado, Boulder, CO 80309, USA \\ ${ }^{3}$ Division of Atmospheric Sciences, Desert Research Institute, Reno, NV 89512, USA \\ ${ }^{4}$ Aerodyne Research Inc., Billerica, MA 01821, USA \\ ${ }^{5}$ TOFWERK AG., 3600 Thun, Switzerland \\ ${ }^{6}$ National Center for Atmospheric Research, Boulder, CO 80301, USA \\ ${ }^{7}$ Department of Atmospheric Sciences, University of Washington, Seattle, WA 98105, USA \\ ${ }^{8}$ Department of Physics, University of Helsinki, 00014 Helsinki, Finland
}

Correspondence to: J. L. Jimenez (jose.jimenez@ colorado.edu)

Received: 8 June 2013 - Published in Atmos. Chem. Phys. Discuss.: 28 June 2013

Revised: 19 December 2013 - Accepted: 20 December 2013 - Published: 11 February 2014

\begin{abstract}
Hundreds of gas- and particle-phase organic acids were measured in a rural ponderosa pine forest in Colorado, USA, during BEACHON-RoMBAS (Bio-hydro-atmosphere interactions of Energy, Aerosols, Carbon, $\mathrm{H}_{2} \mathrm{O}$, Organics \& Nitrogen - Rocky Mountain Biogenic Aerosol Study). A recently developed micro-orifice volatilization impactor highresolution time-of-flight chemical ionization mass spectrometer (MOVI-HRToF-CIMS) using acetate $\left(\mathrm{CH}_{3} \mathrm{C}(\mathrm{O}) \mathrm{O}^{-}\right)$as the reagent ion was used to selectively ionize and detect acids semicontinuously from 20 to 30 August 2011, with a measurement time resolution of $\sim 1.5 \mathrm{~h}$. At this site $98 \%$ of the organic acid mass is estimated to be in the gas phase, with only $\sim 2 \%$ in the particle phase. We investigated gas-particle partitioning, quantified as the fraction in the particle phase $\left(F_{\mathrm{p}}\right)$, of $\mathrm{C}_{1}-\mathrm{C}_{18}$ alkanoic acids, six known terpenoic acids, and bulk organic acids vs. carbon number. Data were compared to the absorptive partitioning model and suggest that bulk organic acids at this site follow absorptive partitioning to the organic aerosol mass. The rapid response $(<1-2 \mathrm{~h})$ of partitioning to temperature changes for bulk acids suggests that kinetic limitations to equilibrium are minor, which is in contrast to conclusions of some recent laboratory and field studies, possibly due to lack of very low ambient relative hu-
\end{abstract}

midities at this site. Time trends for partitioning of individual and groups of acids were mostly captured by the model, with varying degrees of absolute agreement. Species with predicted substantial fractions in both the gas and particle phases show better absolute agreement, while species with very low predicted fractions in one phase often show poor agreement, potentially due to thermal decomposition, inlet adsorption, or other issues. Partitioning to the aqueous phase is predicted to be smaller than to the organic phase for alkanoic and bulk acids, and has different trends with time and carbon number than observed experimentally. This is due to the limited additional functionalization observed for the bulk acids. Partitioning to water appears to only play a role for the most oxidized acids during periods of high aerosol liquid water. Based on measurement-model comparison we conclude that species carbon number and oxygen content, together with ambient temperature, control the volatility of organic acids and are good predictors for partitioning at this site. Partitioning of bulk acids is more consistent with model predictions for hydroxy acids, hydroperoxyacids, or polyacids, and less so for keto acids. 


\section{Introduction}

Organic aerosol (OA) is a substantial fraction of the submicron aerosol mass globally (Murphy et al., 2006; Zhang et al., 2007). Recent studies have demonstrated that a major fraction of OA is secondary (SOA), formed from oxidation of volatile organic compounds (VOCs) in the atmosphere (Jimenez et al., 2009). Despite the importance of SOA for urban, regional, and global submicron aerosols and thus human health effects and climate forcing, its sources, sinks, and properties in the atmosphere are poorly understood (Hallquist et al., 2009). The diversity of SOA sources and molecular products represents tremendous challenges for both measurements and modeling. Therefore, it is not surprising that there are often major discrepancies between modeled and observed SOA concentrations in the atmosphere (de Gouw et al., 2005; Heald et al., 2005; Volkamer et al., 2006).

Possible explanations for these large discrepancies include the lack of consideration by models of (1) semivolatile and intermediate volatility organic compounds (S/IVOCs), which can contribute substantially to SOA formation (Robinson et al., 2007); (2) secondary chemistry in the condensed phase (Kalberer et al., 2004); (3) aqueous-phase reactions in cloud or fog droplets and aerosol particle water (Ervens et al., 2011); (4) nonequilibrium partitioning due to changes in the phase state of SOA (Perraud et al., 2012; Vaden et al., 2011; Virtanen et al., 2010); and (5) enhancement of biogenic SOA by anthropogenic pollution (Spracklen et al., 2011). However, when all these sources are combined, models can produce excessive amounts of SOA, indicating that our current ability to distinguish between SOA formed from different sources and its sinks remains insufficient (Heald et al., 2011; Hodzic et al., 2010). Loss of SOA due to fragmentation reactions followed by volatilization may be important and remains poorly characterized (Chacon-Madrid and Donahue, 2011). The difficulty of models to predict both SOA concentrations and degree of oxidation highlights a critical need for improved understanding of the processes and pathways controlling SOA formation and aging.

Gas-particle partitioning is one of the key processes controlling the formation and lifetime of SOA. Phase partitioning is commonly modeled by equilibrium absorptive partitioning to the OA (Pankow, 1994) using either a two-product approach (Odum et al., 1996), a volatility-basis set (Donahue et al., 2006), or detailed chemical speciation (Aumont et al., 2012; Capouet et al., 2008). Some recent laboratory and field studies have indicated that the assumption of equilibrium partitioning, homogeneous mixing, and liquid-like behavior of OA may be inaccurate, at least under some conditions, and that very long timescales may be needed for gas-particle equilibration (Perraud et al., 2012; RenbaumWolff et al., 2013; Vaden et al., 2011), while other studies suggest the opposite (Saleh et al., 2013). However, due to the complexity of the chemical composition of OA, there are very few ambient studies of the phase partitioning of organic species. Recent field studies have focused on understanding the phase partitioning of a few individual compounds or compound classes (Bao et al., 2012; Fisseha et al., 2006; Fry et al., 2013; Liu et al., 2012; Matsunaga et al., 2005; Terzi and Samara, 2004; Zhao et al., 2013) and bulk water-soluble organic carbon (Hennigan et al., 2009; Zhang et al., 2012).

Terzi and Samara (2004) measured 13 two-to-six ringed polycyclic aromatic hydrocarbons (PAHs) in the gas and particle phases and observed that the PAHs were distributed between the gas and particle phases in a manner consistent with equilibrium partitioning. Matsunaga et al. (2005) measured phase partitioning of several carbonyls in a polluted atmosphere and reported preferential partitioning to the gas phase when compared to a remote location; furthermore, they hypothesized that differences in the composition of polluted and remote aerosol may be leading to changes in partitioning of the carbonyls. Bao et al. (2012) measured several saturated $\left(\mathrm{C}_{2}-\mathrm{C}_{6}\right)$, unsaturated and keto carboxylic acids using a denuder-filter pack system and noted that the gas-particle partitioning of diacids varied diurnally similar to ambient temperature. In addition, they noticed that the particle-phase fraction of oxalic and glyoxylic acids increased with increasing relative humidity (RH) and hypothesized that aerosol water can act as an absorbing medium, thus increasing gasparticle partitioning. Liu et al. (2012) measured phase partitioning of formic acid in Los Angeles, CA, using a realtime technique and observed higher particle-phase formic acid concentration than could be explained by theory. Using measurements collected during the same campaign as this study, Fry et al. (2013) observed that total gas- and particlephase organic nitrates appeared to be distributed according to reversible partitioning. Unlike the abovementioned studies, where only a few compounds or bulk classes were measured, Williams et al. (2010) used a semicontinuous thermal desorption aerosol gas chromatography-mass spectrometry (TAG) instrument to show that several different classes of S/IVOCs partition into OA as a function of their vapor pressure and ambient temperature. However, alkanoic acids were the only type of acids analyzed with the TAG, as more oxidized acids are difficult to analyze with gas chromatography. More recently, Zhao et al. (2013), also using the TAG instrument, observed higher-than-expected concentrations of phthalic acid and pinonaldehyde in the particle phase, while predicted partitioning of 6,10,14-trimethyl-2-pentadecanone was consistent with measurements. They suggested that reactions between phthalic acid and ammonia could produce lowvolatility products that partition more readily to the particle phase, whereas the measured pinonaldehyde is suggested to be a product of thermal decomposition of oligomers during analysis.

Organic acids are ubiquitous in the atmosphere (Chebbi and Carlier, 1996). Over the past three decades researchers have investigated their importance for acid rain in remote atmospheres (Chameides and Davis, 1983), new particle formation (Kavouras et al., 1997), and as tracers for meat 
cooking and combustion (Kawamura et al., 1985; Rogge et al., 1993b). More recently, they have been studied in order to understand oxidation chemistry of anthropogenic and biogenic VOCs and SOA formation in the atmosphere (Andrews et al., 2012; Paulot et al., 2011; Sommariva et al., 2011; Veres et al., 2011; Vogel et al., 2013). However, their formation mechanisms, gas-particle partitioning, and contribution to OA mass are still largely unknown.

Here, we present semicontinuous ( $1.5 \mathrm{~h}$ time resolution) measurements of phase partitioning of organic acids in a ponderosa pine forest. Phase partitioning is calculated using the measured signal for hundreds of organic acids in the gas and particle phases. The fraction in particle phase $\left(F_{\mathrm{p}}\right)$ is investigated as a function of compound carbon number, oxygen content, estimated saturation mass concentration $\left(C^{*}\right)$, and time. We report results for alkanoic acids $\left(\mathrm{C}_{1}\right.$, formic acid $-\mathrm{C}_{18}$, stearic acid), several terpenoic acids, and bulk acids binned by carbon number.

\section{Experimental methods}

\subsection{Study site}

This study was part of BEACHON-RoMBAS (Bio-hydroatmosphere interactions of Energy, Aerosols, Carbon, $\mathrm{H}_{2} \mathrm{O}$, Organics \& Nitrogen - Rocky Mountain Biogenic Aerosol Study, July-August 2011, http://cires.colorado.edu/ jimenez-group/wiki/index.php/BEACHON-RoMBAS), conducted at the NCAR Manitou Forest Observatory field site near Woodland Park, Colorado, USA $\left(39.10065^{\circ} \mathrm{N}\right.$, $105.10250^{\circ} \mathrm{W}$; https://wiki.ucar.edu/display/mfo/Manitou+ Forest+Observatory). The site is a managed ponderosa pine forest at an elevation of $2370 \mathrm{~m}$ above sea level and is representative of ponderosa pine species that extend from northern New Mexico to southern Wyoming. The canopy is open, with an average canopy height of $18 \mathrm{~m}$. The understory is mainly composed of grasses, sage, and exposed cryptogrammic soils. The surrounding forest contains some Douglas fir, oak, spruce, and aspen vegetation, from which VOC emission probably also impacted the site.

Biogenic volatile organic compound (BVOC) emissions at this site are dominated (based on volume mixing ratios) by 2 methyl-3-butene-2-ol (MBO, 50\%) and monoterpenes (major MT: $\beta$-pinene, $\alpha$-pinene, 3 -carene $-33 \%$ ) with a small fraction of aromatics and oxygenated terpenes and sesquiterpenes $(<0.5 \%)$ (Kim et al., 2010). During the campaign period, diurnal variations of $\mathrm{MBO}$ and MT were anticorrelated, with MBO mixing ratios being highest during the day, reaching $\sim 1.5 \mathrm{ppbv}$, and MT being highest during early morning at $\sim 0.8 \mathrm{ppb}$ and lowest during the day (Fry et al., 2013). Local aerosol formation is thought to be dominated by monoterpenes.

\subsection{Sampling inlet}

To minimize losses of gases and aerosol, a specially designed inlet was used (Fig. 1a). The inlet consisted of two parts: (1) a large duct to bring air from above the trailer housing closer to the micro-orifice volatilization impactor high-resolution time-of-flight chemical ionization mass spectrometer (MOVI-HRToF-CIMS) while minimizing turbulence and wall contact and (2) a smaller diameter Silcosteelcoated tube (Restek Corp., Bellefonte, PA, USA) to sample air from the center of the duct to the instrument.

The large duct inlet was made of galvanized steel with an OD of $15.2 \mathrm{~cm}$. To block debris and rain, a conical stainless steel bowl was installed above the inlet tube. The top opening of the inlet tube was covered with a SilcoNert 2000 (Restek Corp., Bellefonte, PA, USA) coated mesh to protect from insects and debris. This was followed by 114 bundled SilcoNert-coated tubes: each $1.27 \mathrm{~cm}$ OD and $6.35 \mathrm{~cm}$ long, to break up larger eddies and minimize turbulence down the larger tube. A high-flow-rate computer fan (Vantech Tornado, model TD9238H), controlled by the program SpeedFan (version 4.43, www.almico.com), was installed at the bottom of the duct. In order to maintain laminar flow, the fan speed was adjusted to a flow rate of $327 \mathrm{~L}$ per minute (Lpm), resulting in a flow velocity of $\sim 0.3 \mathrm{~m} \mathrm{~s}^{-1}$, residence time of $\sim 7 \mathrm{~s}$, and a Reynolds number $(R e)$ of 1920 . The Silcosteel-coated tubing leading to the instrument (OD and ID of $0.95 \mathrm{~cm}$ and $0.66 \mathrm{~cm}$, respectively, and length of $1 \mathrm{~m}$ ) was inserted $2 \mathrm{~m}$ from the top of the duct inlet. Sample flow rate through the Silcosteel coated tubing was $10 \mathrm{Lpm}$, resulting in a flow velocity of $6.5 \mathrm{~m} \mathrm{~s}^{-1}$, residence time of $\sim 0.2 \mathrm{~s}$, and a $R e$ of 2050.

Gas-phase diffusion timescales in the tubing are estimated using diffusion coefficients $(D)$ of nitric acid $\left(\mathrm{HNO}_{3}\right)$ and a straight-chain $\mathrm{C}_{16}$ hydrocarbon in air. The choice of these two compounds is meant to provide a rough estimate of the range of inlet interactions that can be expected for semivolatile to low-volatility acids. Using $D_{\mathrm{HNO}_{3}}=1.18 \times$ $10^{-5} \mathrm{~m}^{2} \mathrm{~s}^{-1}$ (Durham and Stockburger, 1986), the diffusion timescale (i.e., $L^{2} /\left(4^{*} D\right)$, where $L$ is the length scale) is estimated to be $480 \mathrm{~s}$ and $1 \mathrm{~s}$ in the duct inlet and the Silcosteel-coated tubing, respectively. Similarly, if we use $D_{C 16}=3.5 \times 10^{-6} \mathrm{~m}^{2} \mathrm{~s}^{-1}$ (Hilal et al., 2003), the diffusion timescale increases to $1610 \mathrm{~s}$ and $3 \mathrm{~s}$ for the duct inlet and the Silcosteel-coated tubing, respectively. Since diffusion timescales for these representative compounds are larger than the residence times for air in each of the inlet parts, we expect limited gas-phase losses of semivolatile and low-volatility organic acids for the flow conditions used here. The effect of changing ambient $\mathrm{RH}$ on the losses in the sampling tubes was not studied. To minimize gas-phase adsorption on the MOVI walls and the aerosol collection post, they were coated with inert materials (Inertium, AMCX Corp., State College, PA, USA, for aluminum MOVI body and SilcoNert 2000 for stainless steel post). 

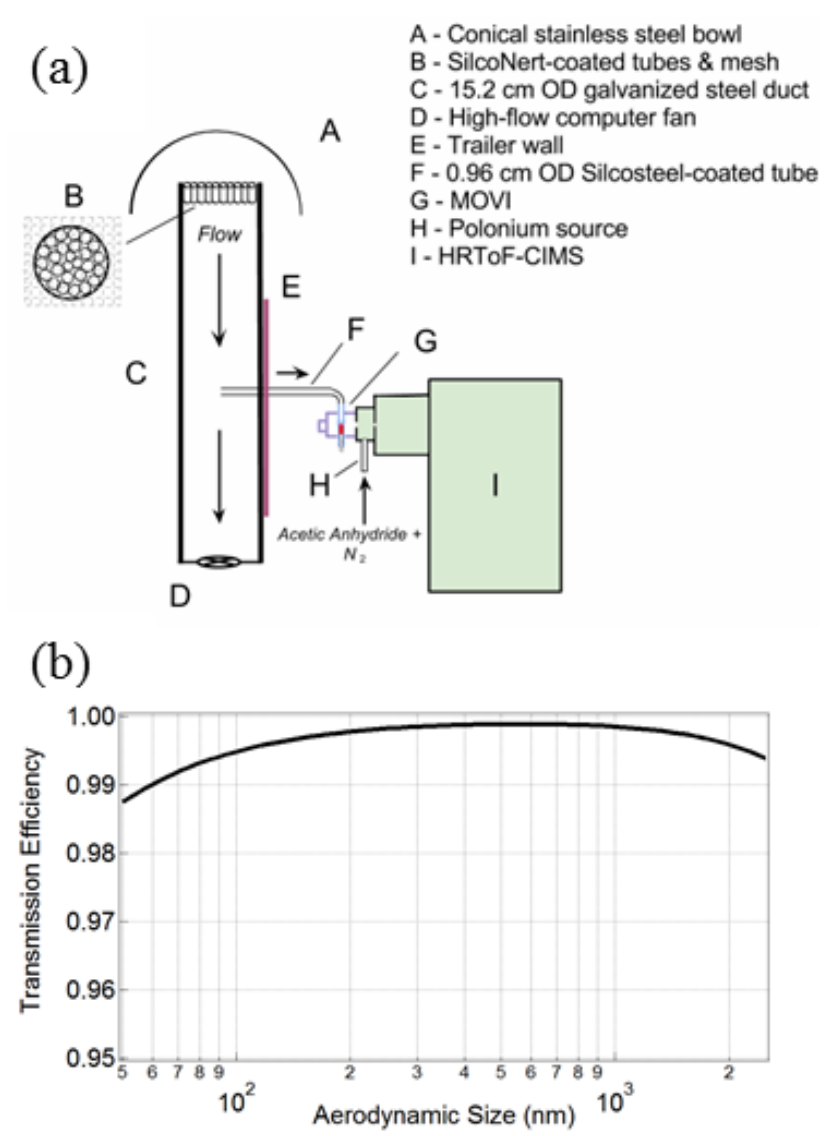

Fig. 1. (a) Schematic of the sampling inlet used during the BEACHON-RoMBAS study, (b) calculated aerosol transmission efficiency of the complete inlet vs. aerodynamic diameter.

Transmission of particles through the inlet was modeled taking into account gravitational settling, inertial deposition, diffusional deposition, and aspiration efficiency for anisoaxial sampling conditions (Baron and Willeke, 2001). Figure 1b shows the calculated transmission efficiency for particle sizes from 0.05 to $2.5 \mu \mathrm{m}$. For all particles in this size range, the transmission efficiency is calculated to be $>99 \%$ for the flow conditions used here.

\subsection{MOVI-HRToF-CIMS operation}

Real-time gas- and particle-phase organic acid measurements were made using the MOVI-HRToF-CIMS instrument (Yatavelli et al., 2012; Yatavelli and Thornton, 2010) (Aerodyne Research Inc., Billerica, MA). Briefly, the MOVI is an inertial impactor with a cut point of $0.13 \mu \mathrm{m}\left(d_{50}\right.$, aerodynamic diameter) at $10 \mathrm{Lpm}$ flow rate. Analysis is a three-step cycle - (1) sampling: gas-phase compounds are measured by the HRToF-CIMS while aerosols are being collected on the MOVI post; (2) aerosol heating: collected aerosols are thermally vaporized in an inert ultra-high-purity (UHP) $\mathrm{N}_{2}$ atmosphere while their composition is measured by the HRToF-
CIMS; and (3) cooling: the MOVI is allowed to cool down to ambient temperature in an inert $\mathrm{N}_{2}$ atmosphere before the sampling step is repeated again. Steps 1, 2, and 3 together are referred to as a "MOVI cycle".

During this field study, key modifications were made to the MOVI cycle to minimize and better estimate the gas and aerosol backgrounds. Along with the three-step MOVI cycle described above, three new steps were included. To measure gas-phase backgrounds, a short 1 min UHP $\mathrm{N}_{2}$ sample step, called blank sampling, was added before each aerosol heating step. An additional thermal desorption step with UHP $\mathrm{N}_{2}$, called blank heating, was also included after each aerosol heating step to measure the background during that cycle and minimize carry-over of organic material to the next MOVI cycle. This extra thermal desorption step also required an additional cooling step, called blank cooling, before repeating the MOVI cycle. The sampling step was $45 \mathrm{~min}$, aerosol and blank heating steps were 8 min each, and cooling steps were $10 \mathrm{~min}$ each for a total cycle time of $77 \mathrm{~min}$. During the aerosol heating step, the MOVI body and post temperatures were linearly ramped from 32 to $200^{\circ} \mathrm{C}$, resulting in a ramp rate of $\sim 20.6^{\circ} \mathrm{C} \mathrm{min}^{-1}$. Material used in the MOVI and its coupling to the instrument limited the maximum temperature to $200^{\circ} \mathrm{C}$. Figure $\mathrm{S} 1$ in the Supplement shows a schematic of the MOVI cycle along with the MOVI post temperature during different steps.

The acetate ion selectively ionizes acids by abstracting a proton from the carboxyl hydrogen (Veres et al., 2008). Both organic and inorganic acids are ionized, but here we focus exclusively on organic acids. We note that acidic alcohols such as nitrated phenols that have gas-phase acidities higher than that of acetic acid will also be ionized and can be measured by proton abstraction (Mohr et al., 2013), while species such as glyoxal, methylglyoxal, and levoglucosan can be measured by clustering with acetate (depending on the declustering setting of the ToF), but with far lower sensitivity (Aljawhary et al., 2013). The ion chemistry with the same ionization region design has been described in the literature (Bertram et al., 2011). Pressures and voltages used in this study are similar to those reported by Yatavelli et al. (2012). The instrument was operated in negative ion mode and ToF mass spectra were acquired at a pulser frequency of $25 \mathrm{kHz}$ resulting in a mass-to-charge ratio $(\mathrm{m} / \mathrm{Q})$ range from 7 to 505 thomson $(\mathrm{Th})$. Spectra were averaged and saved to disk every $0.5 \mathrm{~s}(2 \mathrm{~Hz})$, and the data were further averaged to $5 \mathrm{~s}$ time resolution before analyses. The HRToFMS was operated in $V$ mode with a mass resolving power of $3000 \mathrm{Th} \mathrm{Th}^{-1}$ at $50 \mathrm{Th}$ and increasing to $4200 \mathrm{Th} \mathrm{Th}^{-1}$ at $200 \mathrm{Th}$. Instrument mass accuracy is estimated to be $\pm 20 \mathrm{ppm}$ (Yatavelli et al., 2012). The instrument used here is conceptually similar to that reported by Holzinger et al. (2013), which is also based on impactor collection, thermal desorption, and chemical ionization mass spectrometry (using $\mathrm{H}_{3} \mathrm{O}^{+}$instead of acetate reagent ions). 


\subsection{Data analysis}

Data processing was carried out with the Tofware software package (version 2, TOFWERK AG/Aerodyne/University of Colorado) written in IGOR Pro software (Wavemetrics, Lake Oswego, OR, USA). Built-in analysis procedures are used to perform baseline determination, $m / Q$ calibration, high-resolution multi-peak fitting and elemental composition estimation. The data processing and high-resolution fitting methods are similar to those previously described for the Aerodyne aerosol mass spectrometer (AMS) (DeCarlo et al., 2006). Here, we briefly describe only the most relevant features used for the analyses presented in this manuscript.

Averaged ( $5 \mathrm{~s}$ ) raw mass spectra were first $m / Q$-calibrated and then their baselines determined. Then, empirical peak shape and mass resolution $(m / \Delta m)$ functions were determined from $24 \mathrm{~h}$ average spectra for use in high-resolution fitting, similar to the procedures employed in the analysis of AMS data (DeCarlo et al., 2006). An ion peak list was generated using a multi-peak fitting algorithm and assigned to a list of possible ion elemental compositions. The peak areas of individual ions determined from this procedure were obtained by fitting the raw spectra, using fixed $m / Q$, peak shape, and mass resolution. Isotopes were constrained using natural isotopic ratios and the fitted parent ion areas at lower $m / Q$ and included in the high-resolution fitting of other isobaric ions. Figure S2 in the Supplement shows an example of the high-resolution peak fitting at $183 \mathrm{Th}$.

Due to limited signal and signal-to-noise $(S / N)$ ratio at high $m / Q$, data presented here cover the $m / Q$ range of 40-399 Th, using a total of 1823 ions, which accounted for $>95 \%$ of the total signal. Figure 2 shows mass spectra collected during sampling and aerosol heating steps. During sampling, lower $m / Q(<150)$ compounds are dominant, suggesting that these are mainly present in the gas phase. As $m / Q$ increases the compounds are higher during the aerosol heating step, suggesting that these are increasingly present in the particle phase.

The measured ion peak areas during the heating step are corrected using the collection efficiency curves for palmitic acid aerosol given in Yatavelli and Thornton (2010) and SMPS (TSI 3080 DMA with a 3081 classifier and a TSI 3010 CPC (Shoreview, MN, USA)) measured aerosol size distribution during the sampling step. The average collection efficiency varied between 0.66 and 0.77 .

\subsection{Background subtraction}

For all ions in the peak list, final gas- and particle-phase signal is calculated by subtracting their background signal during the blank sampling and the blank aerosol heating steps, respectively. For the gas phase, the average of only the last 5 min of the sampling step is considered for the analysis to avoid biasing the signal from inlet equilibration effects. For the particle phase, in order to minimize peak-fitting errors due to limited $S / N$ ratio, we averaged the mass spectra for the entire aerosol heating step ( $8 \mathrm{~min})$. After multi-peak fitting, each ion peak signal is divided by two factors that account for the fact that aerosol was allowed to accumulate for $45 \mathrm{~min}$ and for the lower flow rate $(2 \mathrm{Lpm})$ during the aerosol heating step compared to the sampling step $(10 \mathrm{Lpm})$. Finally, using the ion elemental compositions, $F_{\mathrm{p}}$ for each compound is binned into carbon number bins and a signalweighted bin average is calculated. Throughout the rest of this manuscript, this is called "bulk-averaged $F_{\mathrm{p}}$ ". Errors reported here are variable due to changes in ambient temperature and $\mathrm{OA}$, as well as estimated precision calculated using random errors from ion counting, random error due to variation of the single-ion signal intensities, and electronic noise.

Figure $\mathrm{S} 3$ shows the background and ambient signals for $\mathrm{C}_{1}-\mathrm{C}_{18}$ alkanoic acids for 26 August. Data from other days are similar. Background signals are about an order of magnitude lower than gas and particle signals, although there is some variation with carbon number.

\subsection{Phase-partitioning calculation and model}

The particle-phase fraction of an organic acid is defined as the ratio of the measured particle-phase concentration to the total concentration.

$$
F_{\mathrm{p}, i}=\frac{\text { Particle }}{\text { Gas + Particle }}
$$

For instance, an acid present solely in the gas phase will have an $F_{\mathrm{p}}$ of 0 and an acid present solely in the particle phase will have an $F_{\mathrm{p}}$ of 1 .

Phase partitioning is modeled using equilibrium absorptive partitioning theory (Pankow, 1994). Effective saturation mass concentration $\left(C^{*}\right)$ is as described by Donahue et al. (2006), and corresponds to the inverse of the gas-particle partitioning coefficient $\left(C^{*}=1 / K_{\mathrm{p}}\right)$ used in the Pankow formulation. $F_{\mathrm{p}}$ for $i$ in equilibrium and $C^{*}$ is calculated as

$F_{\mathrm{p}, i}=\left(1+\frac{C_{i}^{*}}{C_{\mathrm{OA}}}\right)^{-1}$,

$C_{i}^{*}=\frac{M_{i} 10^{6} \zeta_{i} P_{\mathrm{v}}}{760 R T}$,

where $C_{\mathrm{OA}}\left(\mu \mathrm{g} \mathrm{m}^{-3}\right)$ is the organic aerosol mass concentration, $M_{i}\left(\mathrm{~g} \mathrm{~mol}^{-1}\right)$ is the molecular weight of acid $i, \zeta_{i}$ is the activity coefficient of acid $i$ in the OA mixture (assumed $=1), P_{\mathrm{v}}$ (torr) is the pure-component liquid vapor pressure

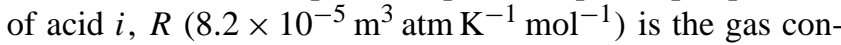
stant, $T(\mathrm{~K})$ is the ambient temperature, and 760 torr atm $^{-1}$ and $10^{6} \mu \mathrm{g} \mathrm{g}^{-1}$ are unit conversion factors for pressure and mass concentration. Alternative formulations of partitioning theory are presented by Pankow (1994) and Cappa (2010). The differences in these three formulations are on the order 


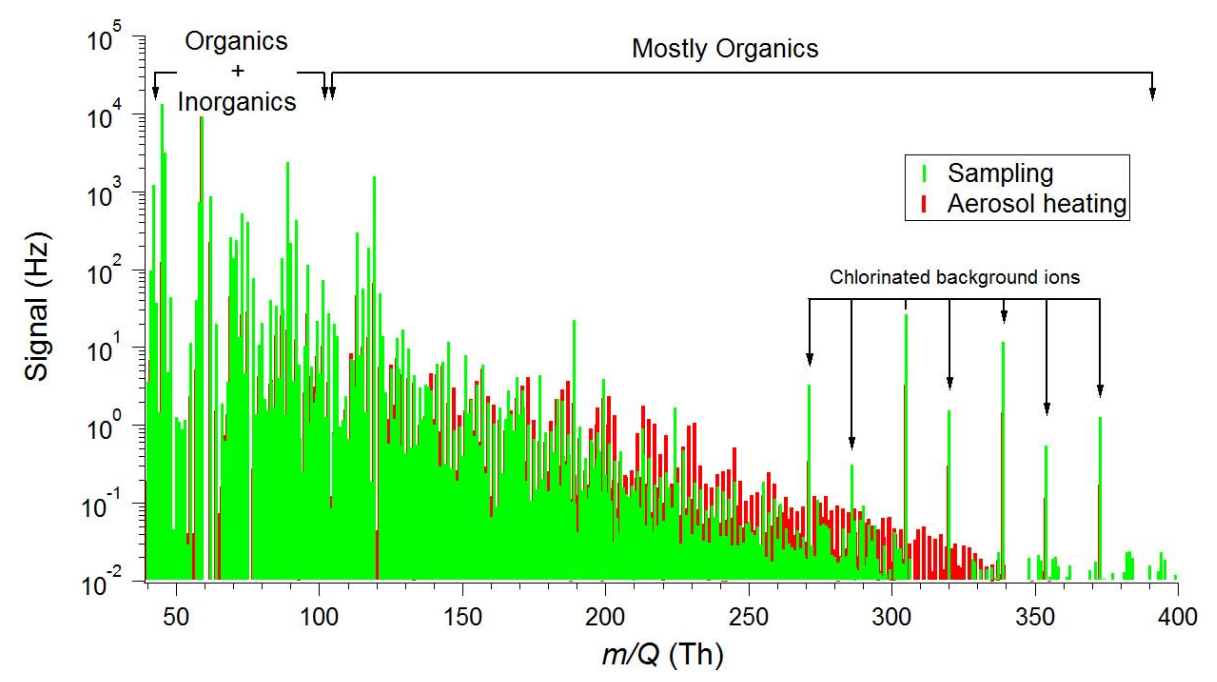

Fig. 2. Mass spectrum showing organic acids measured during the sampling and aerosol heating steps. Signal shown here is backgroundcorrected, and is scaled appropriately for the higher sampling rate of the MOVI.

of $\mathrm{MW}_{i} / \mathrm{MW}_{\mathrm{OA}}$, and similar or smaller than uncertainties in vapor pressures and activity coefficients, and therefore we do not consider them further. $P_{\mathrm{v}}$ and enthalpies of vaporization ( $\Delta H_{\text {vap }}$, used to determine the temperature dependence of $\left.P_{\mathrm{v}}\right)$ are taken from the literature. Because of the uncertainty in $P_{\mathrm{v}}$ and $\Delta H_{\mathrm{vap}}$ values from reported laboratory experiments and group contribution methods, several different sources are used to model phase partitioning, thus minimizing reliance on any one particular source. Experimentally determined $P_{\mathrm{v}}$ and $\Delta H_{\mathrm{vap}}$ are from the Reaxys database (2012), Cappa et al. (2008), and Chattopadhyay and Ziemann (2005). Vapor pressures from group contributions methods of Nannoolal (2008) and Myrdal and Yalkowsky (1997) are estimated using the University of Manchester multiphase system online property prediction (UManSysProp, 2012) tool for a temperature of $298 \mathrm{~K}$.

Vapor pressure values are corrected for ambient temperature using the Clausius-Clapeyron equation. Solid-phase vapor pressures and enthalpies of sublimation values are converted into $P_{\mathrm{v}}$ and $\Delta H_{\text {vap }}$ (Poling et al., 2001) using the entropy of fusion and melting temperature from the NIST Chemistry WebBook (Linstrom and Mallard, 2005). The corrected values of $P_{\mathrm{v}}$ are used to calculate $C^{*}$ and estimate $F_{\mathrm{p}}$ of each acid using Eqs. (2) and (3), as well as $C_{\mathrm{OA}}$, the measured total OA from a collocated high-resolution aerosol mass spectrometer (AMS, Aerodyne Research Inc.) (Fry et al., 2013). For the "campaign average" model calculation, the average OA mass concentration was $1.9 \pm 0.6 \mu \mathrm{g} \mathrm{m}^{-3}$, as measured by the AMS on site and average ambient temperature was $290 \mathrm{~K}$. Tables S1 and S2 in the Supplement list the $P_{\mathrm{v}}, C^{*}$, and $\Delta H_{\mathrm{vap}}$ as well as their corresponding references.

\section{Results and discussion}

Hundreds of organic acids were measured in the gas and particle phase during this campaign. Using an average sensitivity (from mono-, di-, and tri-acids) we estimate particlephase organic acid mass concentration to be approximately $0.6 \mu \mathrm{g} \mathrm{m}^{-3}$, which is similar to that reported recently at a boreal forest site (Vogel et al., 2013). Using the same estimated sensitivity for all acids, $\sim 98 \%$ of the organic acid mass is present in the gas phase, with only $\sim 2 \%$ in the particle phase (Fig. 2).

\subsection{Phase partitioning of alkanoic acids}

Figure 3 shows the observed phase partitioning and model results for $\mathrm{C}_{1}$ to $\mathrm{C}_{18}$ alkanoic acids. Results are limited to $\leq \mathrm{C}_{18}$ because of increasing measurement uncertainties associated with very low gas- and particle-phase concentrations and the nonavailability of $P_{\mathrm{v}}$ and $\Delta H_{\text {vap }}$ values above $\mathrm{C}_{18}$. These acids represent on average $1.3 \%$ of the total acid mass (assuming similar sensitivities for all acids). The data shown here are a campaign average for 20-30 August 2011. Results for individual days are similar (not shown). As expected, acids with higher volatility (lower carbon numbers) are mainly in the gas phase, and as the carbon number increases, the associated $C^{*}$ decreases (see Table $\mathrm{S} 1$ in the Supplement), thereby increasing $F_{\mathrm{p}}$. An increase in $F_{\mathrm{p}}$ is clearly seen starting with $\mathrm{C}_{14}$ alkanoic acid and increasing with carbon number. Reasons for higher $F_{\mathrm{p}}$ at carbon numbers $<\mathrm{C}_{14}$ are discussed below.

Modeled $F_{\mathrm{p}}$ with different $P_{\mathrm{v}}$ and $\Delta H_{\mathrm{vap}}$ data sets span the gray-shaded region in Fig. 4. Model results using $P_{\mathrm{v}}$ for the linear acids from Cappa et al. (2008) form the upper limit, whereas those using $P_{\mathrm{v}}$ from Myrdal and Yalkowsky (1997) constitute the lower limit. We note that isomers such as 


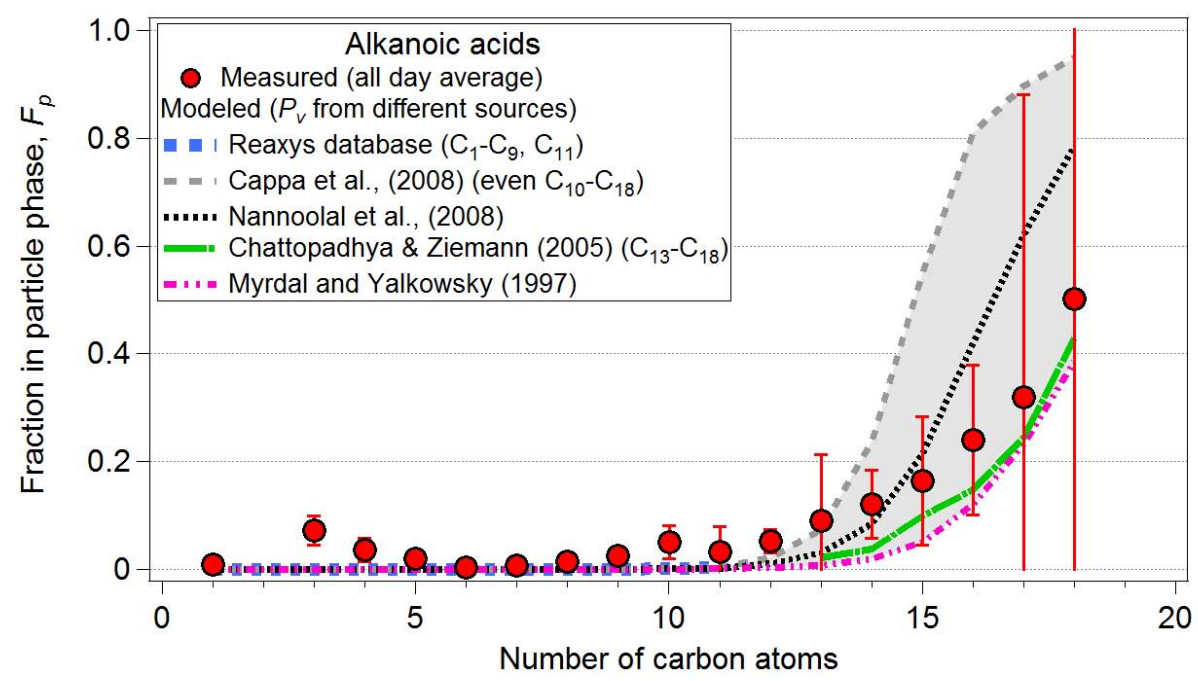

Fig. 3. Measured and modeled $F_{\mathrm{p}}$ as a function of carbon number for alkanoic acids. Error bars represent measurement precision and variability due to ambient temperature and OA changes.

branched acids may also be present and cannot be distinguished from the linear acids with this technique. The measurement-model agreement is good with the transition from gas-phase dominance to substantial particle-phase fraction starting at the $\mathrm{C}_{13}$ alkanoic acid in both the measurements and the models. Below $\mathrm{C}_{13}$, the model results indicate that alkanoic acids should be mainly in the gas phase, whereas the observed $F_{\mathrm{p}}$ show low but non-zero values. Below we discuss possible reasons for this discrepancy. Above $\mathrm{C}_{13}, F_{\mathrm{p}}$ rapidly increases for both measurements and model, with good agreement within the combined uncertainties. Therefore, the campaign-averaged data indicate that alkanoic acids appear to be close to thermodynamic equilibrium partitioning, within the uncertainties of the measurements and the model. In a recent study by Williams et al. (2010), where similar analysis was conducted for gas- and particle-phase alkanoic acids observed in Riverside, CA, the observed $F_{\mathrm{p}}$ was much higher, even at lower carbon numbers. Their data were closer to model-calculated $F_{\mathrm{p}}$ with $\zeta<0.1$, which was attributed to incomplete gas-phase collection in their technique.

\subsection{Possible reasons for measurement-model discrepancies}

This section summarizes all the possible reasons for measurement-model discrepancies. Although the discrepancies are smaller for the alkanoic acids than some of the other acids shown below, we list all the potential reasons here for clarity.

The higher observed $F_{\mathrm{p}}$ for alkanoic acids of lower carbon numbers, compared to the modeled results, may be due to several reasons. First, here we are assuming that the change of air mass at the site is slower than the gas-particle equilib- rium timescales - that is, we are assuming that we are studying a parcel of air in a Lagrangian manner - but advection of different air masses could play a role in some of the observed changes. Second, adsorption of semivolatile or polar organic compounds to the walls of the MOVI can result in higher signal during the aerosol heating step, leading to higher apparent $F_{\mathrm{p}}$. In order to minimize this positive artifact, backgrounds are subtracted from the gas and aerosol signals as discussed above; however due to the complexity of the sampling and analysis cycle, those may not completely capture the true background signal levels. In addition, although the MOVI walls and collection post are coated with inert materials to limit adsorption, the inertness of these coatings in terms of limiting adsorption of organic acids has not been tested in detail. Third, with ambient aerosol containing thousands of compounds, a substantial fraction of which are highly oxidized and have multiple functional groups, production of low-molecular-weight organic acids by thermal decomposition (Moldoveanu, 2010) may play a role in the higher $F_{\mathrm{p}}$ for the smaller alkanoic acids. For example, higher-molecularweight compounds such as oligomers with high $F_{\mathrm{p}}$ could thermally decompose during the aerosol heating step or fragment after ionization (less likely) to produce low-molecularweight acids, giving the appearance of the presence of small acids with higher-than-expected $F_{\mathrm{p}}$ (Williams et al., 2007; Zhao et al., 2013).

Another possible reason for higher $F_{\mathrm{p}}$ values at lower molecular weights is the possible effects of mechanisms other than absorption to the OA on partitioning for more volatile acids. A study by Liu et al. (2012) in Los Angeles, $\mathrm{CA}$, observed a small concentration of formic acid in the particle phase that was several orders of magnitude higher than could be accounted for by a partitioning model using Henry's law. Keene et al. (2004) also observed higher fractions of 


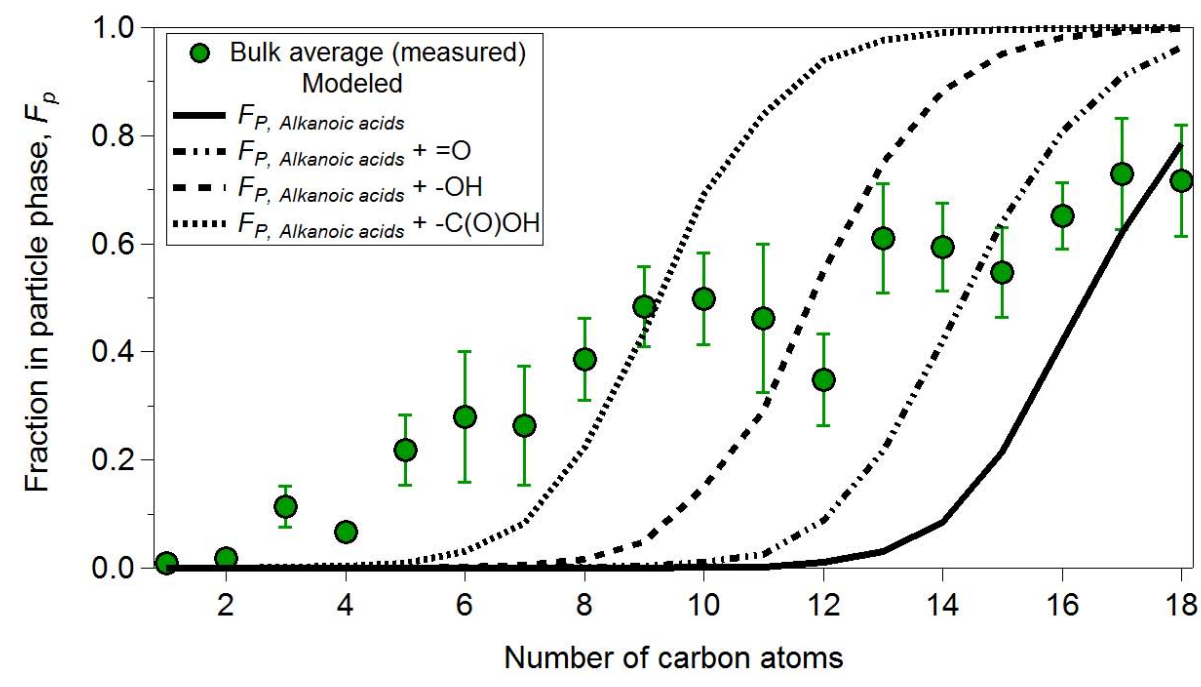

Fig. 4. Campaign average of $F_{\mathrm{p}}$ for bulk-averaged data binned into carbon number bins. Also shown is $F_{\mathrm{p}}$ calculated from gas-particle partitioning theory for (right to left) alkanoic acids and alkanoic acids with the addition of a carbonyl, hydroxyl or a carboxyl group. Error bars represent measurement precision and variability due to ambient temperature and OA changes.

formic and acetic acids in the particle phase than expected, although they speculated that this may be due to artifacts in their extraction or analytical procedure. Partitioning of the acids to the aqueous phase is one such possible mechanism, but for our data set, the estimated partitioning to the aerosol aqueous phase is $<10^{-4}$, much lower than the observed $F_{\mathrm{p}}$ (see Fig. S4 in the Supplement) and has the opposite trend with carbon number as observed in the measurements. This estimation was from a maximum aerosol liquid water content of $25 \mu \mathrm{g} \mathrm{m}^{-3}$, which was calculated using the Extended Aerosol Inorganic Model II (Clegg et al., 1998; E-AIM, 2012) and Henry's law constants of $C_{1}-C_{12}$ alkanoic acids. This indicates that dissolution of alkanoic acids in the aerosol aqueous phase should be minimal, and does not explain the high $F_{\mathrm{p}}$ values for lower carbon number acids shown in Fig. 3. It is also possible that kinetic limitations to evaporation play a role. Moreover, using the recently reported laboratory experiments on viscosity changes with RH (Renbaum-Wolff et al., 2013), we do not expect major particle-phase diffusion limitations, since RH was $>30 \%$ most of the time at the site (see Fig. S5 in the Supplement). It is also possible that the more volatile acids are present as complexes with metals (Furukawa and Takahashi, 2011; Xing et al., 2013), which could increase their particle-phase fraction.

Differences in formulations of partitioning theory (Cappa, 2010; Pankow, 1994) vs. the Donahue et al. (2006) formulation used here, and/or activity coefficients different from the value of 1 assumed here, could also result in some differences. However, both reasons should only result in limited changes to the calculated $F_{\mathrm{p}}$. As discussed above, differences between the partitioning formulations are on the order of $\mathrm{MW}_{i} / \mathrm{MW}_{\mathrm{OA}}$, and should only be substantial for the lightest acids. Recent studies have shown that activity coefficients for oxidized organics deviate only by a factor of 2-3 from 1 (Donahue et al., 2011; Shiraiwa et al., 2013), which is not large enough to change the model results substantially.

\subsection{Phase partitioning of bulk-averaged acids}

Figure 4 shows bulk-averaged $F_{\mathrm{p}}$ (i.e., the observed $F_{\mathrm{p}}$ for all the species detected with the MOVI-HRToF-CIMS) binned into carbon number bins $\left(\mathrm{C}_{1}-\mathrm{C}_{18}\right)$ and averaged over the entire measurement period. $F_{\mathrm{p}}$ increases with increasing carbon number starting at $\mathrm{C}_{3}$, unlike for alkanoic acids, where partitioning was observed to increase at $\mathrm{C}_{14}$. This suggests that a substantial fraction of organic acids with lower carbon numbers have low enough volatility to partition substantially into the particle phase, e.g., dicarboxylic acids and polycarboxylic acids, or other multifunctional compounds with at least one carboxylic acid group. Another interesting observation is the decrease in $F_{\mathrm{p}}$ starting at $\mathrm{C}_{10}$ and having two local minima at $\mathrm{C}_{12}$ and $\mathrm{C}_{15}$ carbons before increasing again. The reasons for the observed trends are discussed below.

Also plotted in Fig. 4 is the model-calculated $F_{\mathrm{p}}$ for alkanoic acids, together with additional model results showing the effect of increasing functionality (by the addition of one carbonyl, hydroxyl, or a carboxyl functional group to the alkanoic acids) on $F_{\mathrm{p}}$. The effect of increasing functionality is to reduce the volatility of the acids, thereby increasing $F_{\mathrm{p}}$. Estimated reductions in $C^{*}$ from the addition of a carbonyl (0.1), hydroxyl $\left(5.7 \times 10^{-3}\right)$ or a carboxyl $\left(3.1 \times 10^{-4}\right)$ functional group are based on the simplified group contribution method (SIMPOL.1) (Pankow and Asher, 2008). The addition of a hydroperoxyl group $(-\mathrm{OOH})$ reduces $\mathrm{C}^{*}$ by approximately a factor of $2.3 \times 10^{-3}$, which is in between the 
addition of a $-\mathrm{OH}$ and a $-\mathrm{C}(\mathrm{O}) \mathrm{OH}$ group. Based on the concentration of $\mathrm{NO}$, alkyl peroxy $\left(\mathrm{RO}_{2}\right)$, and hydroperoxy radicals at the site (Fry et al., 2013), it is estimated that a larger fraction of $\mathrm{RO}_{2}$ radicals at the site react with $\mathrm{NO}$ and thus $\mathrm{OOH}$ groups are not expected to be dominant, although they are expected to be present. Organic nitrates were present at the site and their aerosol concentration was quantified by two different methods, which showed good agreement (Fry et al., 2013). According to Fry et al. (2013) molecules with an organic nitrate group comprised about 6-20\% of OA. From our calibrations (not shown here) we estimate organic acids to comprise $30 \%$ of OA, some fraction of which could be nitrated acids. Quantifying the fraction of acids that have a nitrate group might be possible from the high-resolution spectra, and should be explored in future studies. The individual models that assume addition of an extra functional group per molecule overlap further with the observed data, suggesting that the ambient partitioning of bulk organic acids may be strongly influenced by additional functionalities that may change with carbon number. This is especially apparent for $\leq \mathrm{C}_{8}$, where even with two carboxyl groups the model still predicts lower than the observed $F_{\mathrm{p}}$.

Since the elemental composition of all the ions detected is known from the high-resolution mass spectra, an improved modeling approach is possible by making use of the known oxygen content of the detected ions. We define "detected excess $\mathrm{O}$ " as the number of oxygens in excess of the minimum of two needed for a carboxylic group; that is, excess oxygen is the number of oxygens in the elemental composition minus 2 . The calculated excess oxygen at each ion peak is assumed to lower $C^{*}$ (below that of the alkanoic acid with the same carbon number) proportionally as if all the excess oxygen were present in either carbonyl, hydroxyl, or carboxyl functional groups. This addition of extra functional groups lowers $C^{*}$, which in turn increases the model $F_{\mathrm{p}}$. Note that the model results from hydroxyl and carboxyl additions are reversed in Fig. 5 compared to Fig. 4, because in Fig. 4 one group of each type was added to the alkanoic acids, while in Fig. 5 for the same amount of $\mathrm{O}$ added, $-\mathrm{OH}$ groups are most effective in lowering $C^{*}$. A bin average is then calculated from model $F_{\mathrm{p}}$ of individual compounds, weighted by their absolute signal levels. Figure 5 shows the measured average $F_{\mathrm{p}}$ (same as in Fig. 4) together with the model results using excess oxygen. Also shown is the signal-weighted excess oxygen calculated for each carbon number bin, which varied between 0 and 1.9.

Models using excess oxygen reproduce the trend in the observed $F_{\mathrm{p}}$ reasonably well, indicating that the number of oxygens in ambient multifunctional acids is a controlling factor for their volatility. The models using hydroxyl or acid groups for the excess $\mathrm{O}$ reproduce the observed values better. The presence of abundant acid and hydroxyl functionalities is consistent with a recent study on aging of OA by $\mathrm{Ng}$ et al. (2011). These authors used high-resolution AMS PMF factors from multiple studies to show that OA ages in a way that is consistent with the addition of both acid and hydroxyl/hydroperoxides groups without fragmentation or the addition of an acid with fragmentation. The models with hydroxyl or acid groups also capture the decrease in $F_{\mathrm{p}}$ at 12 and 15 carbons, indicating that those decreases may be a result of the decrease in oxygen-containing functional groups in these bins. A possible reason for the decrease in $\mathrm{O} / \mathrm{C}$ at those carbon numbers may be higher relative fractions of alkanoic acids. In fact, a larger fraction of the signal in these bins is from acids with only two oxygens (no excess $\mathrm{O}$ ), which have a higher volatility compared to more functionalized acids, resulting in a decrease in the bulk average $F_{\mathrm{p}}$. The feature is strongest at 12 carbons, where $\sim 60 \%$ of the signal in the gas phase is contributed by the alkanoic acid (deprotonated dodecanoic acid, $\mathrm{C}_{12} \mathrm{H}_{23} \mathrm{O}_{2}^{-}$) (see Fig. $\mathrm{S} 6$ in the Supplement for the gas- and particle-phase signals for various ions in the $\mathrm{C}_{12}$ bin on 26 August 2011). Dodecanoic acid and other alkanoic acids are both naturally occurring (from plant waxes and oils) and have also been reported in wood combustion, vehicular, and meat cooking emissions (Rogge et al., 1991, 1993a, b).

Above $\mathrm{C}_{15}$, all the models converge, indicating that the influence of the identity of the functional group becomes small compared to the decrease in $C^{*}$ due to the increasing carbon number. Between $\mathrm{C}_{4}$ and $\mathrm{C}_{15}$, the differential effect of specific functionalities is substantial. As above, Henry's law partitioning to the aqueous phase predicts $F_{\mathrm{p}}$ that is several orders of magnitude smaller than partitioning to the organic fraction. Figure 6 shows the estimated aqueous partitioning of bulk-averaged acids using $\mathrm{H}$ values of pure mono- and di-acids and multifunctional acids (see Fig. S7 in the Supplement for the different $H$ values used in this estimation). Overall, we conclude that carbon number and oxygen content appear to control the volatility of organic acids and explain the observed trends in the bulk acid observations.

\subsection{Time series of observed and predicted $\boldsymbol{F}_{\mathrm{p}}$}

Data from each MOVI cycle along with Eq. (1) are used to calculate the time series in phase partitioning, diurnal variation, and correlation coefficients of observed and predicted $F_{\mathrm{p}}$, as shown in Figs. 7-15. The measured $F_{\mathrm{p}}$ is then compared to the absorptive partitioning model using ambient temperatures and the AMS-measured OA mass concentrations. Below, measured and modeled $F_{\mathrm{p}}$ vs. time are shown for (1) bulk-averaged acids (Figs. 7-9), (2) alkanoic acids (Figs. 10-12), and (3) six organic acids that are consistent with known monoterpene oxidation products (and their isomers) (Figs. 13-15). Along with a long time series from 20 to 30 August, a closer analysis of one day, 26 August 2011, is presented for a larger number of species. This day was typical of other days, but was chosen because of complete data collection. Meteorological parameters and OA for 26 August are shown in Fig. S8. 


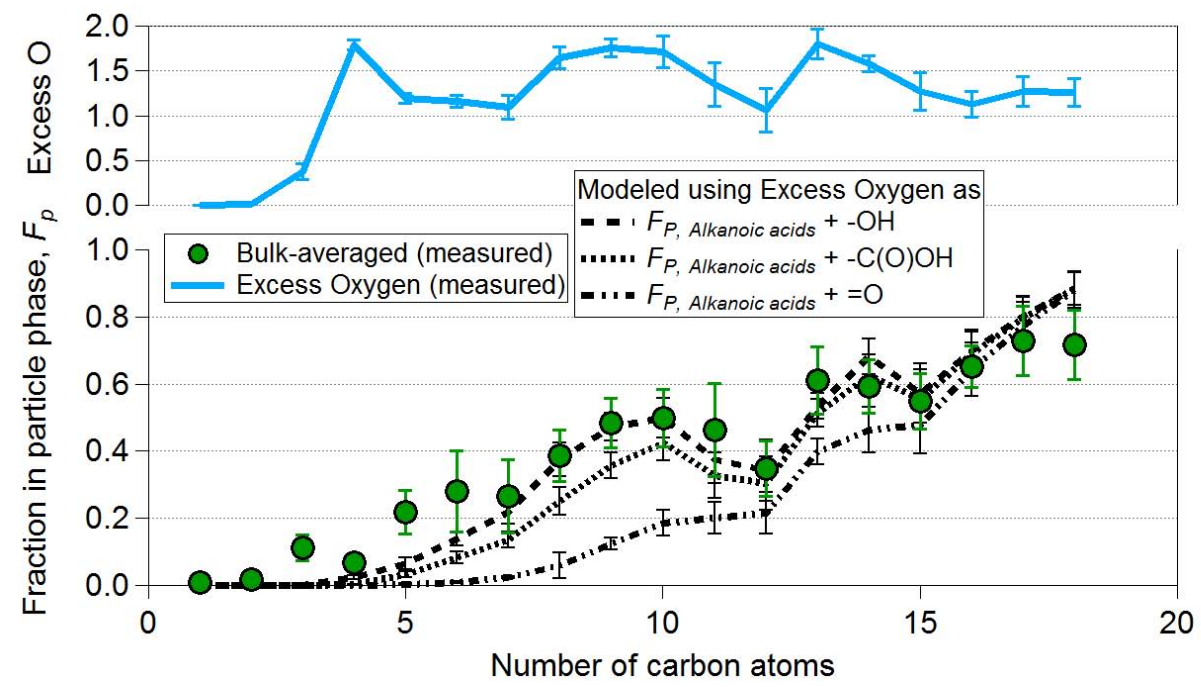

Fig. 5. Campaign average of (bottom) $F_{\mathrm{p}}$ for bulk-averaged data binned into carbon number bins and the (top) excess oxygen (above the two O's needed for alkanoic acids). Also shown is $F_{\mathrm{p}}$ calculated using excess oxygen with its effect on $C^{*}$ calculated as carbonyl, hydroxyl, or carboxyl groups. Error bars for measured data represent measurement precision and variability due to ambient temperature and OA changes. Error bars for modeled data are from the ambient temperature and OA variability.

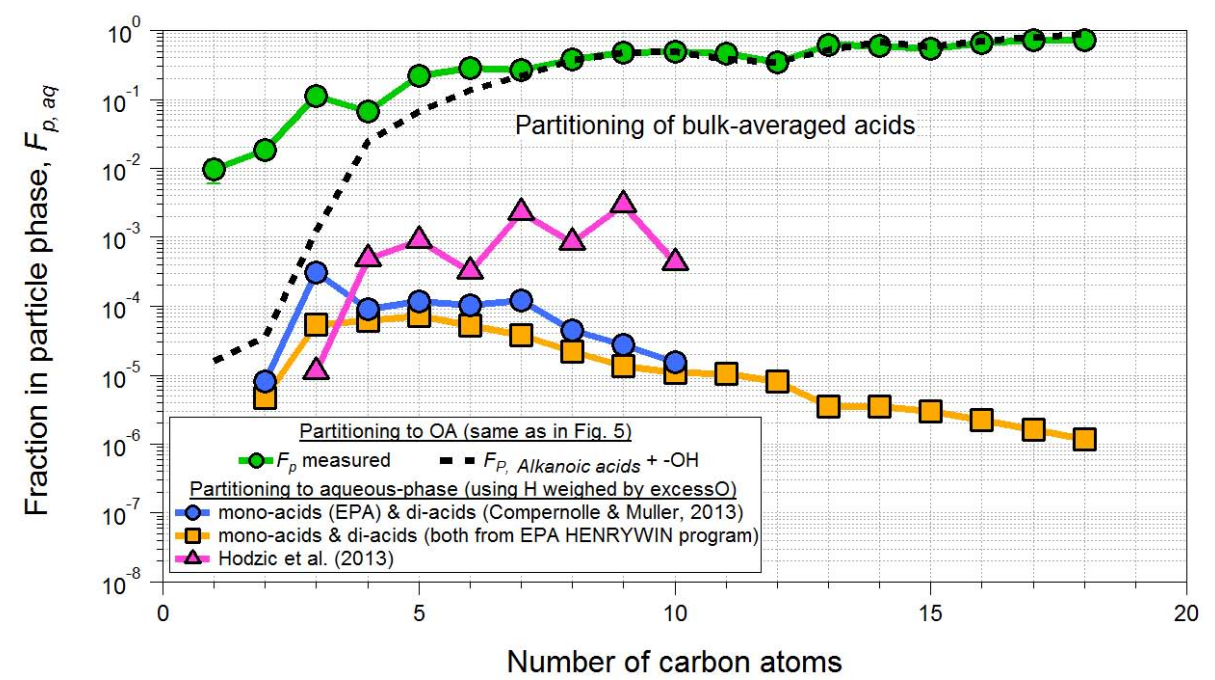

Fig. 6. Campaign average partitioning to the aqueous phase $\left(F_{\mathrm{p}, \mathrm{aq}}\right)$ for bulk-averaged acids $(H$ values used for this estimation are shown in Fig. S7). Also shown are measured and modeled OA $F_{\mathrm{p}}$ from Fig. 5.

\subsubsection{Bulk-averaged acids}

Figures 7 and 8 show the time series, diurnal average, and scatter plot of measured and modeled $F_{\mathrm{p}}$ for the $\mathrm{C}_{7}-\mathrm{C}_{9}$ and $\mathrm{C}_{10}-\mathrm{C}_{12}$ bulk acids, respectively, while Figs. S9-S12 show results for $\mathrm{C}_{1}-\mathrm{C}_{3}, \mathrm{C}_{4}-\mathrm{C}_{6}, \mathrm{C}_{13}-\mathrm{C}_{15}$, and $\mathrm{C}_{16}-\mathrm{C}_{18}$, and Fig. 9 shows the time series on 26 August 2011 from $C_{1}$ to $C_{18} . F_{p}$ for bulk-averaged acids shows a clear diurnal cycle anticorrelated with ambient temperature. In the model, $C^{*}$ for each carbon number is calculated using the $C^{*}$ for the alkanoic acid, with a decrease calculated using the measured average excess oxygen added as hydroxyl functionality (per Fig. 5).
In Figs. 7-9, the trends with carbon number and time of day are generally captured by the model, with the absolute values being well captured for the intermediate carbon numbers. This indicates that the compounds in these bins are semivolatile and appear to follow equilibrium partitioning between gas and particle phases without much delay after ambient temperature changes. The rapid response of partitioning of bulk acids to temperature changes suggests that kinetic limitations to equilibrium are minor at this site. The particle-phase fractions of acids with low and high carbon numbers are over and underpredicted, respectively, by the 


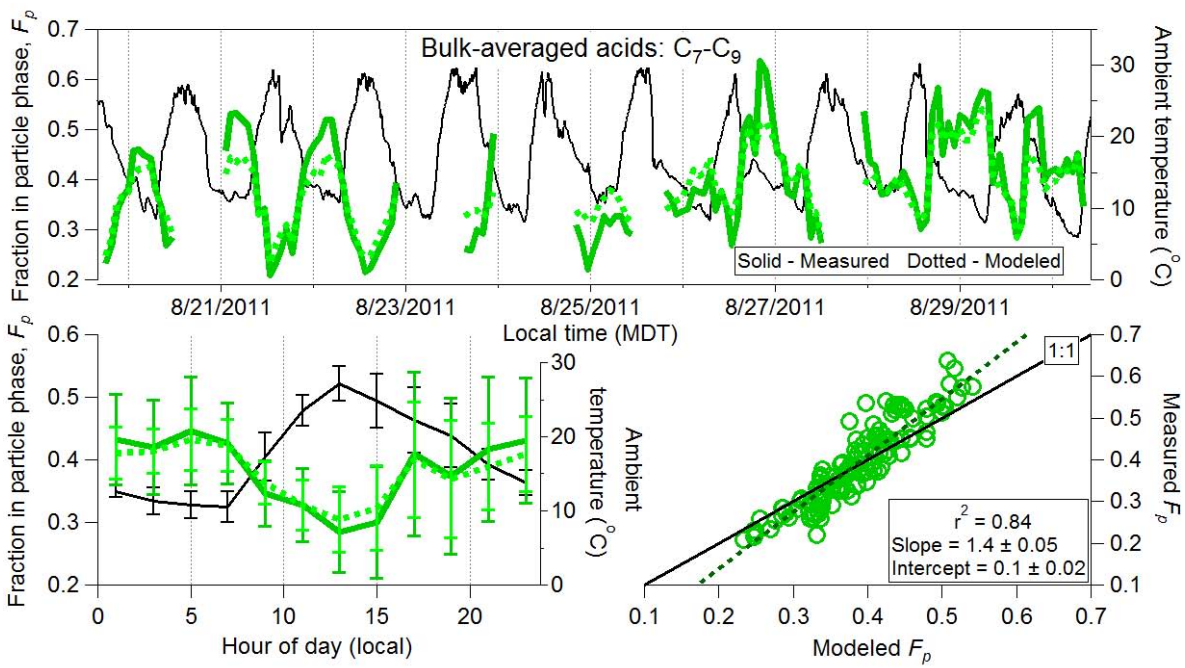

Fig. 7. Time series, diurnal cycle, and scatter plot of measured and modeled $F_{\mathrm{p}}$ for $\mathrm{C}_{7}-\mathrm{C}_{9}$ averaged bulk acids. Model uses excess oxygen as a hydroxyl group.

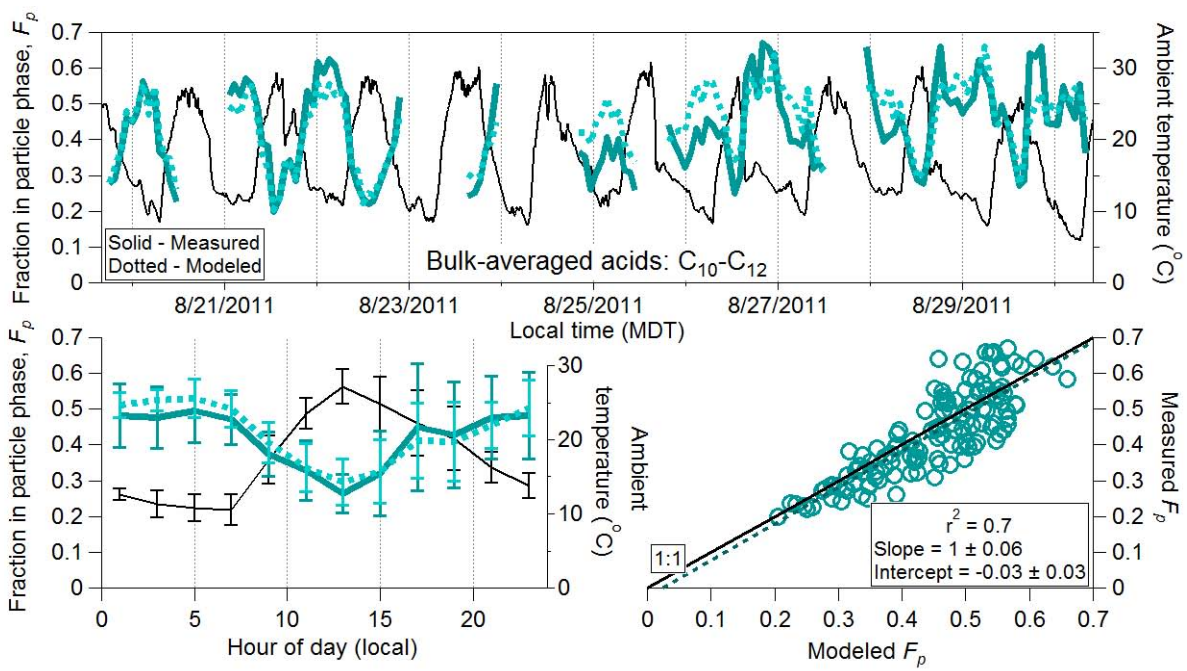

Fig. 8. Time series, diurnal cycle, and scatter plot of measured and modeled $F_{\mathrm{p}}$ for $\mathrm{C}_{10}-\mathrm{C}_{12}$ averaged bulk acids. Model uses excess oxygen as a hydroxyl group.

model. Besides the reasons discussed above, it is also possible that variations in the detailed speciation of the acids during the day lead to a difference in partitioning, as these results are calculated with the excess $\mathrm{O}$ added in the form of hydroxyl groups. Aqueous partitioning estimated for $\mathrm{C}_{7}-\mathrm{C}_{9}$ and $\mathrm{C}_{10}-\mathrm{C}_{12}$ bulk acids is shown in Figs. S13 and S14, which show that their estimated partitioning to the aerosol water is minimal compared to the partitioning to the organic fraction.

\subsubsection{Alkanoic acids}

Figure 10 shows the time series, diurnal average, and scatter plot of measured and modeled $F_{\mathrm{p}}$ for the $\mathrm{C}_{12}$ alkanoic acid (dodecanoic acid and isomers). Measured $F_{\mathrm{p}}$ varied between 0.02 and 0.14 during the 10-day time period. These values are a factor of 2 to 10 higher than those predicted by the absorptive partitioning model for the same carbon number. Several potential reasons for the higher measured $F_{\mathrm{p}}$, compared to that modeled, have been discussed earlier in Sect. 3.2. In addition, the data show weaker diurnal variation than seen in the model. In contrast, the measured $F_{\mathrm{p}}$ for $\mathrm{C}_{16}$ alkanoic acid (palmitic acid) shown in Fig. 11 is within a factor of 2 compared to the model results. This acid does show a substantial diurnal variation, although not as pronounced as the model. Despite a diurnal cycle, low correlation between measured and modeled $F_{\mathrm{p}}$ indicates factors other than ambient temperature (e.g., some of the factors discussed in Sect. 3.2) 


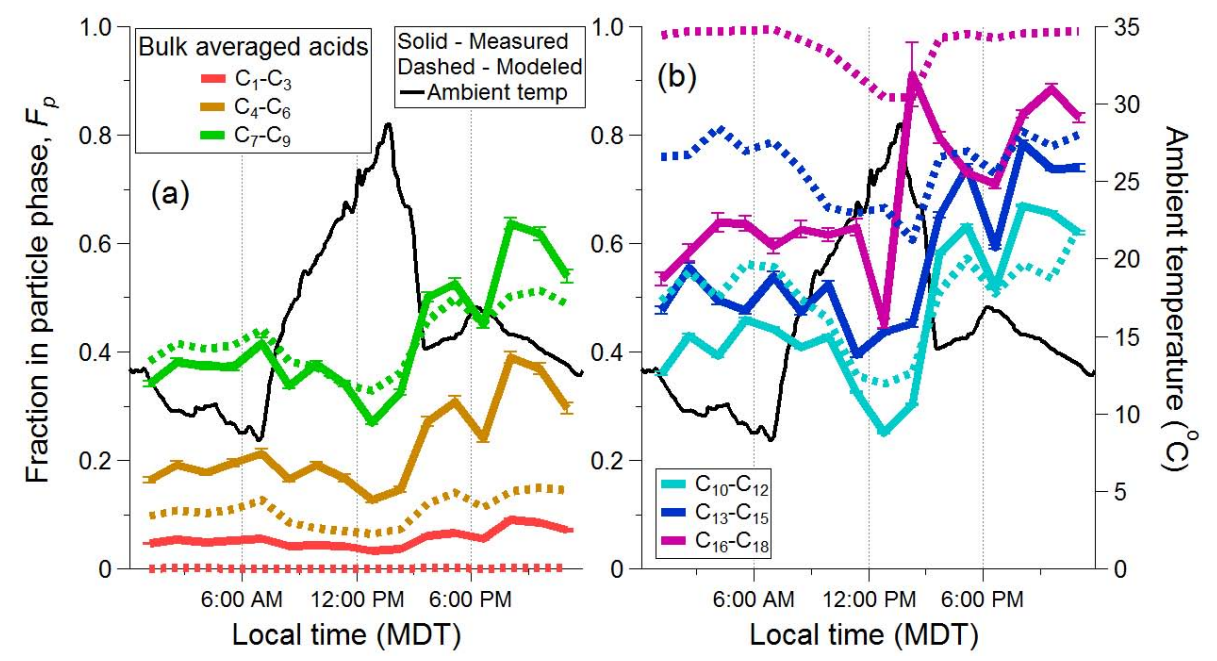

Fig. 9. Time series of $F_{\mathrm{p}}$ for $\mathrm{C}_{1}-\mathrm{C}_{18}$ bulk-averaged acids on 26 August 2011. Also shown are model results where excess oxygen is added as a hydroxyl group. Data and model results are further averaged into different carbon number bins.

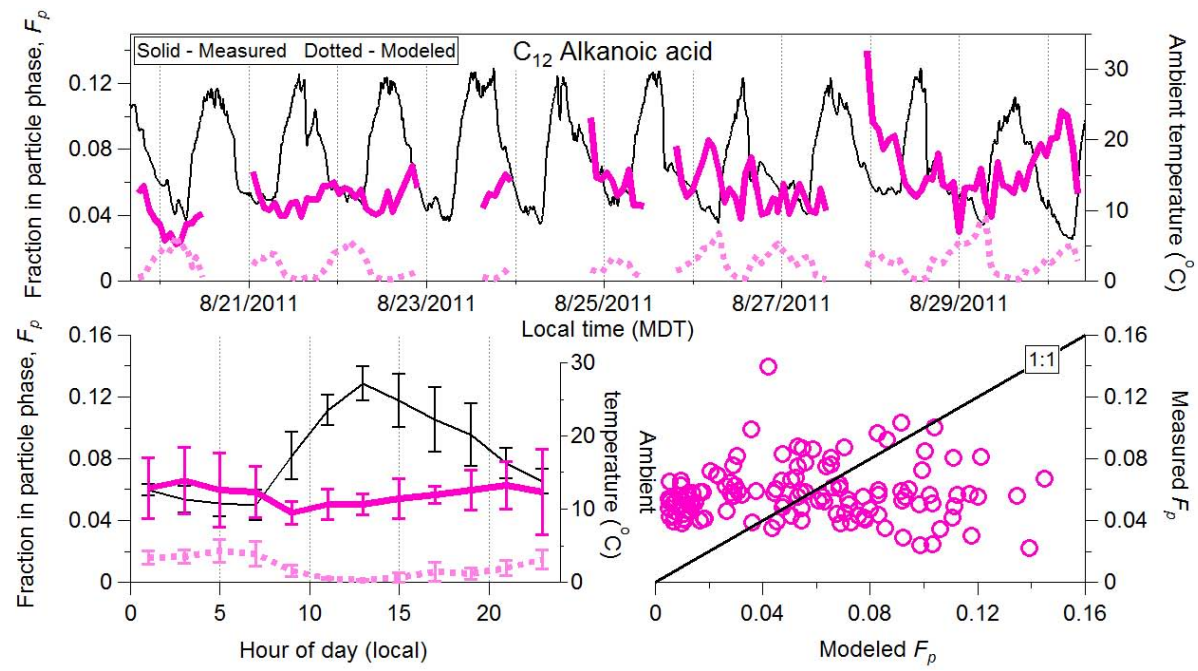

Fig. 10. Time series, diurnal cycle, and scatter plot of measured and modeled $F_{\mathrm{p}}$ for $\mathrm{C}_{12}$ alkanoic acid.

are affecting the phase partitioning or the $F_{\mathrm{p}}$ measurement of alkanoic acids.

A closer view of the phase partitioning of $\mathrm{C}_{1}-\mathrm{C}_{18}$ alkanoic acids is shown for 26 August 2011 in Fig. 12. Data and model results are averaged for three carbon numbers to improve $S / N$ ratio. Measured $F_{\mathrm{p}}$ values for $\mathrm{C}_{1}-\mathrm{C}_{12}$ alkanoic acids vary between 0.01 to 0.1 . The measured values are several orders of magnitude higher than those predicted by the absorptive partitioning model for the same carbon number range, suggesting that there should be very little particlephase concentration of these acids. In addition, the model also indicates a pronounced diurnal cycle for $\mathrm{C}_{1}-\mathrm{C}_{9}$ alkanoic acids, which is not observed in the morning. However, the observed increase in $F_{\mathrm{p}}$ for $\mathrm{C}_{1}-\mathrm{C}_{9}$ acids during the afternoon, when ambient temperature dropped by $15^{\circ} \mathrm{C}$ within
$2 \mathrm{~h}$, is also seen in the model results. For $\mathrm{C}_{13}-\mathrm{C}_{15}$ alkanoic acids, the observed and modeled profiles show similar $F_{\mathrm{p}}$ values during the night, but the measured data show a less pronounced variation with ambient temperature during the afternoon than the model does. In addition, ambient OA mass concentrations also increased during the same time period. Therefore, the increase in observed and modeled $F_{\mathrm{p}}$ later in the day may be due to a combination of lower ambient temperatures and more $\mathrm{OA}$.

\subsubsection{Terpenoic acids}

We also investigated the phase partitioning of deprotonated ions of six known terpenoic acids (including their structural isomers): $\mathrm{C}_{5} \mathrm{H}_{7} \mathrm{O}_{5}^{-}$(hydroxy glutaric acid), 


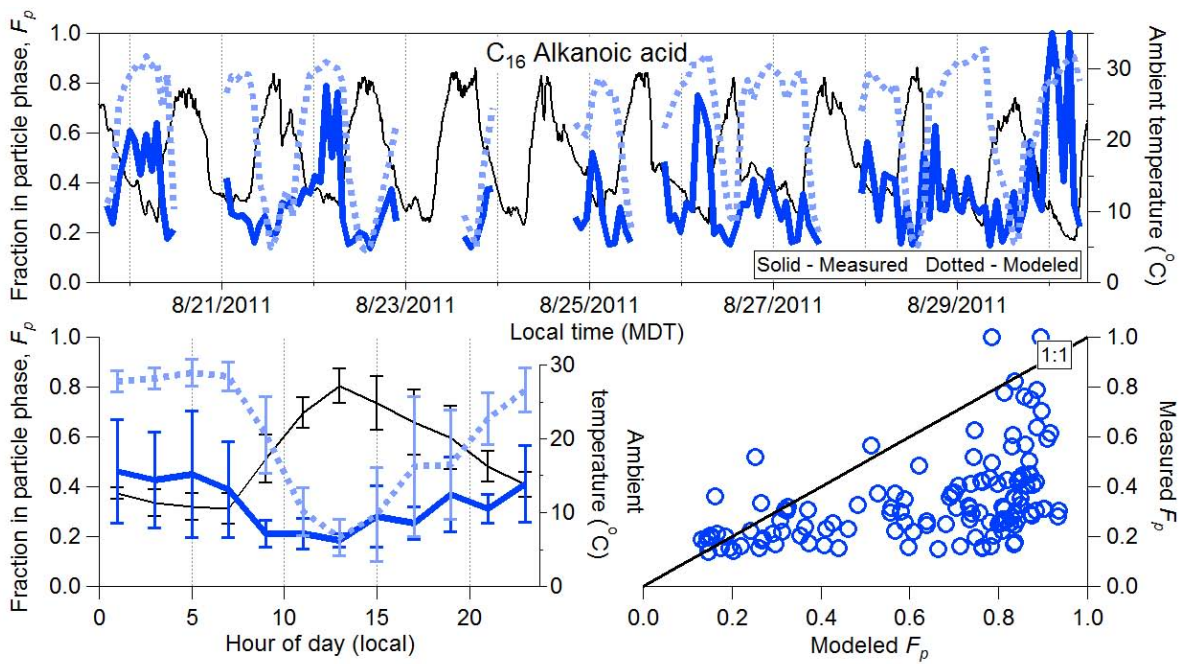

Fig. 11. Time series, diurnal cycle, and scatter plot of measured and modeled $F_{\mathrm{p}}$ for $\mathrm{C}_{16}$ alkanoic acid.

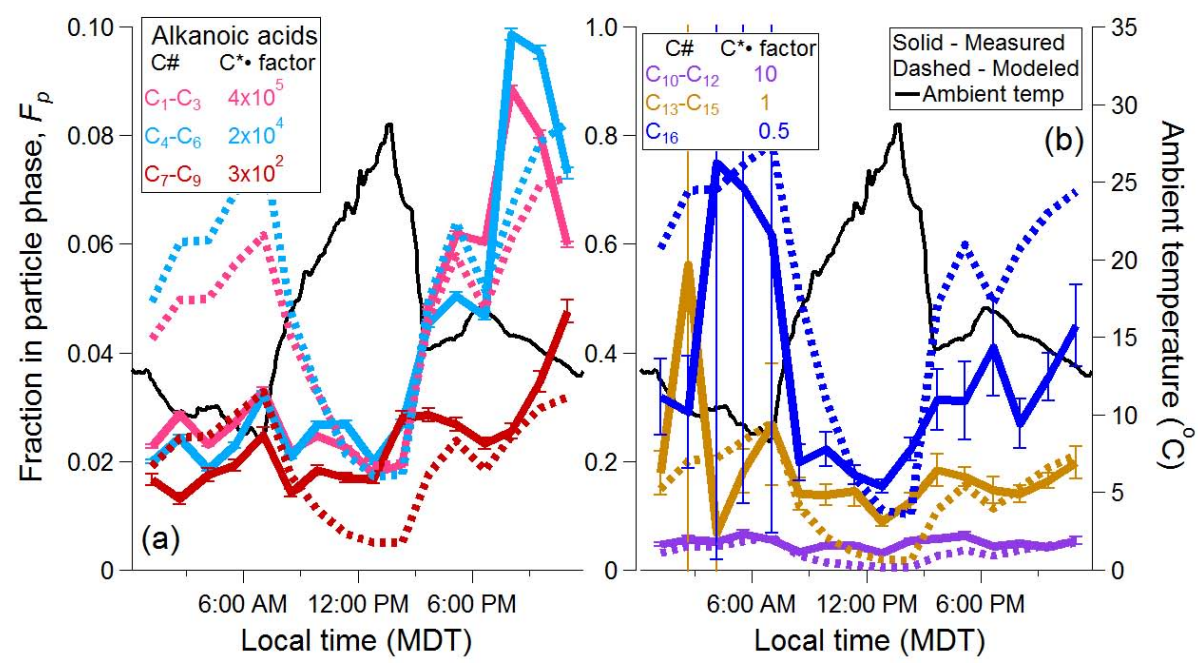

Fig. 12. Time series of measured (solid) and modeled (dashed) $F_{\mathrm{p}}$ for alkanoic acids on 26 August 2011 averaged into different carbon number bins. Multiplicative factors used to increase or decrease the $C^{*}$ for model results to allow comparison of relative trends with the data are also shown in the legend. Note the change in $y$-axis scale for the left and right panels.

$\mathrm{C}_{8} \mathrm{H}_{11} \mathrm{O}_{4}^{-}$(terpenylic acid), $\mathrm{C}_{8} \mathrm{H}_{11} \mathrm{O}_{6}^{-}$(3-methyl-1,2,3butanetricarboxylic acid, MBTCA), $\mathrm{C}_{10} \mathrm{H}_{15} \mathrm{O}_{3}^{-}$(pinonic acid), $\mathrm{C}_{10} \mathrm{H}_{15} \mathrm{O}_{4}^{-}$(hydroxy pinonic acid), and $\mathrm{C}_{9} \mathrm{H}_{13} \mathrm{O}_{4}^{-}$ (pinic acid). These compounds were chosen because they are known oxidation products of monoterpenes, which are expected to dominate local SOA formation at the site (Jaoui and Kamens, 2003; Szmigielski et al., 2007; Yasmeen et al., 2011), and past studies have either estimated or experimentally determined their $P_{\mathrm{v}}$ and $\Delta H_{\mathrm{vap}}$ values (Bilde and Pandis, 2001; Muller et al., 2012; Salo et al., 2010). $\Delta H_{\text {vap }}$ values for pinonic acid, hydroxy pinonic acid, and MBTCA have been estimated using Eq. (12) of Epstein et al. (2010). Table $\mathrm{S} 2$ in the Supplement lists the $P_{\mathrm{v}}, C^{*}$, and $\Delta H_{\mathrm{vap}}$ used here and the corresponding references for these compounds.
These acids represent on average $\sim 0.01 \%$ of the total acid mass (assuming similar sensitivities for all acids).

Similar to the analyses presented above, Fig. 13 shows the times series, diurnal variation, and correlation of measured and modeled $F_{\mathrm{p}}$ for pinic acid. The measured values show similar magnitudes and time trends as the model results, strongly suggesting that pinic acid partitioning is largely controlled by ambient temperature. The response to temperature changes appears to be fast, similar to results above for bulk acids, although the amplitude of the response in $F_{\mathrm{p}}$ is smaller for the measurements. Aqueous partitioning of pinic acid (see Fig. S15) is a strong function of aerosol LWC and can contribute significantly during periods of high aerosol LWC (e.g., on 27 August), but during other times when aerosol 
LWC is low, aqueous partitioning is estimated to be minimal. The experimental time trends are more consistent with the modeled partitioning to the organic fraction than to LWC.

Unlike pinic acid, measured and modeled $F_{\mathrm{p}}$ values for MBTCA (Fig. 14) do not match well. Measured $F_{\mathrm{p}}$ shows a clear diurnal cycle and is always lower than the modeled $F_{\mathrm{p}}$, which is $\sim 1$. Similar to partitioning to OA, MBTCA is estimated to partition readily to aerosol water, even during low aerosol LWC periods. Figure S16 shows the aqueous partitioning of MBTCA along with partitioning to OA. The discrepancy between measured $F_{\mathrm{p}}$ and modeled $F_{\mathrm{p} \text {,aq }}$ indicates towards a possibility that either the $H$ value used here is high or the elemental composition assigned as MBTCA is that of an isomeric compound with higher $P_{\text {vap }}$ and lower $H$ than that used here.

Time series of $F_{\mathrm{p}}$ for the six terpenoic acids on 26 August 2011 are shown in Fig. 15. As expected, the observed $F_{\mathrm{p}}$ increases with decreasing $C^{*}$. For pinonic acid, $C^{*}$ is estimated to be $\sim 10^{3} \mu \mathrm{g} \mathrm{m}^{-3}$, suggesting that it is an intermediate-volatility organic compound (IVOC, $300<C^{*}<3 \times 10^{6} \mu \mathrm{g} \mathrm{m}^{-3}$, Donahue et al., 2012a) that should mainly be in the gas phase. The observed $F_{\mathrm{p}}$ of pinonic acid is between 0.1 and 0.3 , a substantially larger particle-phase fraction than that predicted using its $C^{*}$. On the other hand, MBTCA is estimated to have a $C^{*}$ of $\sim 10^{-3} \mu \mathrm{g} \mathrm{m}^{-3}$ making it a low-volatility organic compound (LVOC, $3 \times 10^{-4}<C^{*}<0.3 \mu \mathrm{g} \mathrm{m}^{-3}$ ) and therefore should be completely present in the particle phase, while high but still lower $F_{\mathrm{p}}$ of $0.7-0.95$ is observed. Other terpenoic acids shown here have $C^{*}$ values in between those of pinonic acid and MBTCA, and they are observed to partition proportionally more to the particle phase according to the relative trend predicted by the model.

On 26 August 2011, most of the terpenoic acids show a stronger response of $F_{\mathrm{p}}$ to changing ambient temperature in the afternoon, with a minimum $F_{\mathrm{p}}$ observed at the highest ambient temperatures. This is clearly seen for the semivolatile acids: hydroxy glutaric, terpenylic, pinic, and hydroxy pinonic acids, suggesting that these acids are evaporating from the particle phase to re-establish the gas-particle equilibrium as ambient temperature changes. Especially interesting are the changes in $F_{\mathrm{p}}$ around 15:00 (local time), when a sudden decrease in ambient temperature coincides with a sudden increase in partitioning to the particle phase, and a smaller change in $F_{\mathrm{p}}$ around 18:00 LT, when a brief increase in ambient temperatures corresponds to decrease in $F_{\mathrm{p}}$ for these compounds. To investigate the effect of changing ambient temperature and OA on phase partitioning of organic acid, we performed two simulations in which either the ambient temperature or ambient OA were held constant (Fig. S17 in the Supplement). These results clearly indicate that temperature is expected to be the major driver of phase partitioning at this site, with variations in OA playing a much smaller role.
Also included in Fig. 15 are modeled $F_{\mathrm{p}}$ values. As discussed above, the trends with $C^{*}$ and time of day observed in the data are captured by the model. In terms of absolute agreement, the model calculations are in reasonable agreement for pinic and hydroxy pinonic acids, especially later in the day. For pinonic acid (IVOC), the model underestimates $F_{\mathrm{p}}$, while for MBTCA (LVOC) it overestimates $F_{\mathrm{p}}$. Some of the reasons that could lead to this model-measurement discrepancy are similar to those described for alkanoic acids. Furthermore, it has to be noted that isomeric compounds with the same elemental compositions but different volatilities are not differentiated with the current instrument. Therefore, if there are different compounds contributing to the detected ions at this location, this could lead to a discrepancy between modeled and observed $F_{\mathrm{p}}$. Another possible source of discrepancy may be the uncertainties in $P_{\mathrm{v}}$ and $\Delta H_{\text {vap }}$ values used here.

\section{Implications for equilibration timescales}

Despite all the uncertainties, the data clearly indicate that semivolatile acids undergo reversible phase partitioning following changes in ambient temperature, as predicted by the adsorptive partitioning model. The data presented here allow us to obtain an approximate estimate of the equilibration timescale for bulk acids as being on the order of $1-2 \mathrm{~h}$ at most. This is similar to recent estimates of a timescale of minutes to hours (this range is most probably due to differences in the aerosol condensation sink considered by the studies) reported for semivolatile compounds by three different studies using laboratory-generated $\alpha$-pinene SOA (Saleh et al., 2013), the VBS approach and theoretical considerations (Donahue et al., 2012b), and a kinetic-flux model (Shiraiwa and Seinfeld, 2012). For semisolid particles (diffusion coefficient $\sim 10^{-15} \mathrm{~cm}^{2} \mathrm{~s}^{-1}$ ) at the OA mass concentrations $\left(2-3 \mu \mathrm{g} \mathrm{m}^{-3}\right.$ ) and particle diameters (volume-weighted mean diameter $\sim 200 \mathrm{~nm}$ ) observed at BEACHON, gas-particle equilibration timescales are estimated to be $3-6 \mathrm{~h}$ (Shiraiwa and Seinfeld, 2012), which suggests that the diffusion coefficients of organic molecules in the particles in our study are $>10^{-15} \mathrm{~cm}^{2} \mathrm{~s}^{-1}$. Similar estimation using the study of Saleh et al. (2013) yields an equilibration timescale of $1 \mathrm{~h}$. Our observations are in contrast to some other recent studies that suggested kinetic limitation to gas-particle partitioning leading to irreversible uptake of semivolatile compounds and extremely slow equilibration (Perraud et al., 2012; Vaden et al., 2011). Renbaum-Wolff et al. (2013) suggest that kinetic limitations to evaporation of $\alpha$-pinene SOA should be observed mostly below $30 \% \mathrm{RH}$, and thus the typically higher humidities observed at our site may be the reason for the lack of strong limitations. 


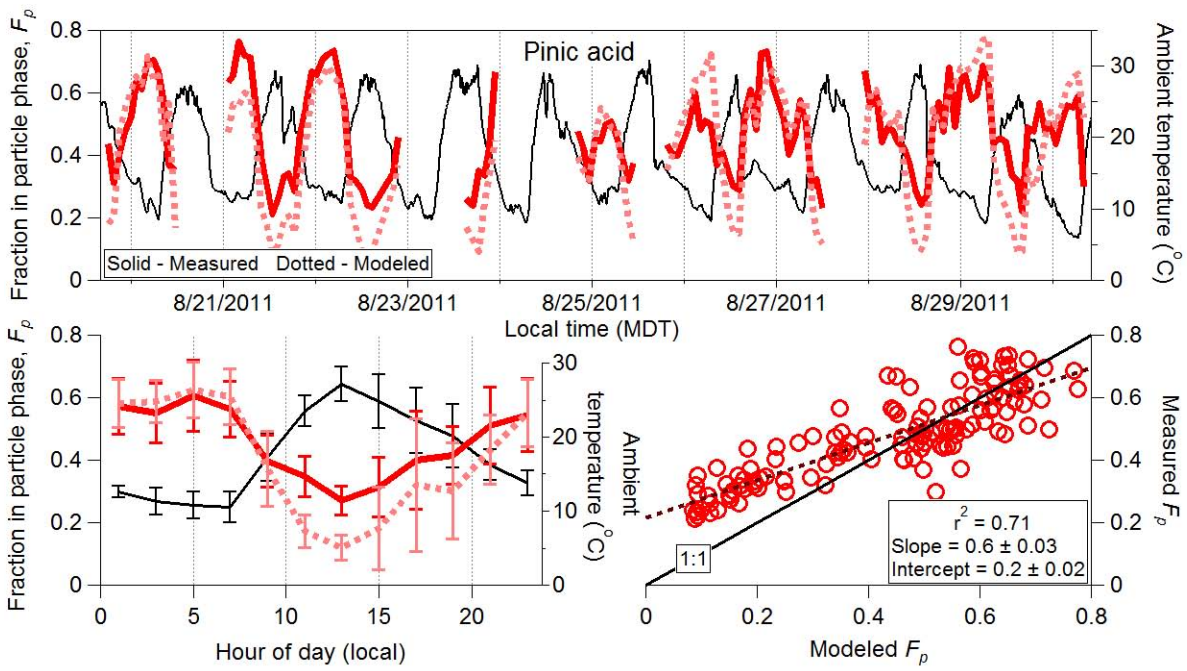

Fig. 13. Time series, diurnal cycle, and scatter plot of measured and modeled $F_{\mathrm{p}}$ for $\mathrm{C}_{9} \mathrm{H}_{13} \mathrm{O}_{4}^{-}$(pinic acid).

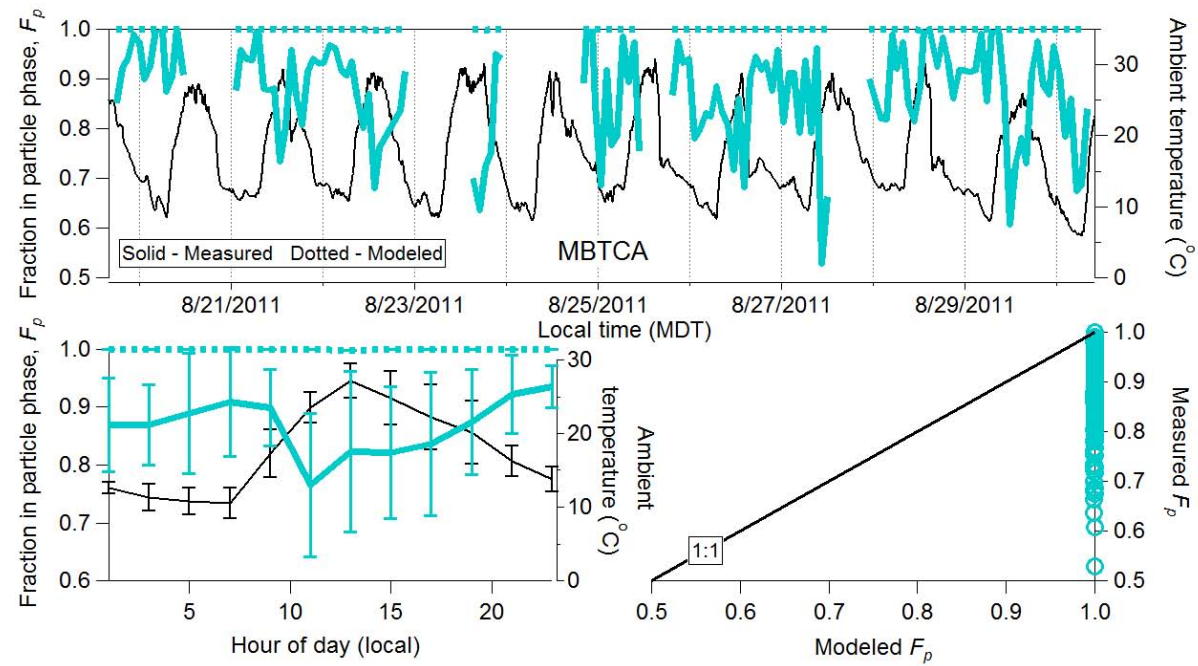

Fig. 14. Time series, diurnal cycle, and scatter plot of measured and modeled $F_{\mathrm{p}}$ for $\mathrm{C}_{8} \mathrm{H}_{11} \mathrm{O}_{6}^{-}$(3-methyl-1,2,3-butanetricarboxylic acid, MBTCA).

\section{Conclusions}

Phase partitioning of organic acids was measured during the BEACHON-RoMBAS field study in a ponderosa pine forest using the recently developed MOVI-HRToF-CIMS technique with acetate as the reagent ion. Hundreds of organic acids were measured in both gas and particle phases, with about $98 \%$ of the total acid mass being present in the gas phase. The observed fractions in the particle phase, $F_{\mathrm{p}}$, were calculated for $\mathrm{C}_{1}-\mathrm{C}_{18}$ alkanoic acids, six known terpenoic acids, and bulk-averaged acids vs. carbon number. Data were compared to equilibrium absorptive partitioning model and good agreement was observed for the trends with carbon number in all cases, and for absolute values for several cases. Acids with predicted extremely low and high values of $F_{\mathrm{p}}$ tend to show larger disagreements. Possible reasons for modelmeasurement discrepancies in some cases are effects of advection and boundary layer mixing or change of air masses, adsorption in the MOVI and inlet, thermal decomposition and/or ion fragmentation of oligomers and large acids to smaller acids, uncertainties in vapor pressures and enthalpies of vaporization, the presence of different isomers at each composition than those assumed in our calculations, and possibly the impact of other partitioning mechanisms. Henry's law partitioning to the aqueous aerosol phase would predict the opposite trend with carbon number and different trends in time than those observed, and does not seem to play a significant role for alkanoic or bulk acid partitioning, owing to the limited functionalization of bulk acids at this site. For the most oxidized acids with high Henry's law coeffi- 


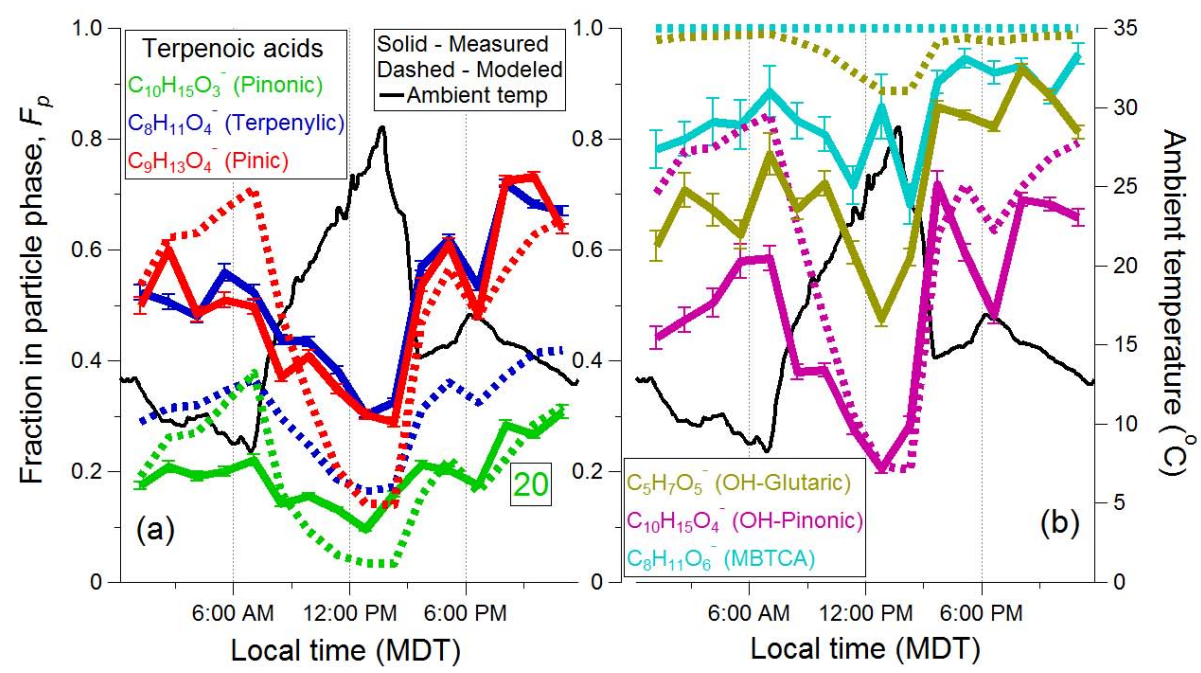

Fig. 15. Time series of $F_{\mathrm{p}}$ for six known terpenoic acids (including isomers) measured on 26 August 2011. Also shown are model results of $F_{\mathrm{p}}$. The pinonic acid model result is multiplied by a factor of 20 to allow comparison of relative trend with the data and is shown in the same color.

cients, partitioning to the aqueous phase can at times contribute substantially to the overall partitioning and is strong function of the aerosol liquid water content. Despite these uncertainties, this study confirms that absorptive partitioning to the OA, driven mainly by changes in ambient temperature, is the major driver of phase partitioning of organic acids at this site. Carbon number and excess oxygen content of organic acids are the controlling parameters of $C^{*}$. Comparison of the measurements to the absorptive partitioning model suggests that reversible gas-particle equilibrium occurs on a timescale of $1-2 \mathrm{~h}$, contrary to several recent studies suggesting irreversible kinetically limited uptake or equilibration timescales of weeks to days, possibly due to the fact that $\mathrm{RH}$ is $>30 \%$ most of the time at this site.

\section{Supplementary material related to this article is available online at http://www.atmos-chem-phys.net/14/ 1527/2014/acp-14-1527-2014-supplement.pdf.}

Acknowledgements. We thank Andrew Turnipseed of NCAR for providing meteorological data, and Alex Guenther and Jim Smith of NCAR as co-organizers of the BEACHON-RoMBAS campaign. We also thank Nathan Kreisberg of Aerosol Dynamics Inc.; Arthur Chan of University of California, Berkeley; and Bill Dube of NOAA for useful discussions on inlet design. This study was partially supported by the National Science Foundation (ATM-0919189 \& AGS-1243354), the Department of Energy SBIR \& BER/ASR (DE-SC0006035), and the University of Colorado Innovative Seed Grant.

Edited by: R. Holzinger

\section{References}

Aljawhary, D., Lee, A. K. Y., and Abbatt, J. P. D.: High-resolution chemical ionization mass spectrometry (ToF-CIMS): application to study SOA composition and processing, Atmos. Meas. Tech., 6, 3211-3224, doi:10.5194/amt-6-3211-2013, 2013.

Andrews, D. U., Haeazlewood, B. R., Maccarone, A. T., Conroy, T., Payne, R. J., Jordan, M. J. T., and Kable, S. H.: Phototautomerization of acetaldehyde to vinyl alcohol: a potential route to tropospheric acids, Science, 337, 1203-1206, 2012.

Aumont, B., Valorso, R., Mouchel-Vallon, C., Camredon, M., LeeTaylor, J., and Madronich, S.: Modeling SOA formation from the oxidation of intermediate volatility n-alkanes, Atmos. Chem. Phys., 12, 7577-7589, doi:10.5194/acp-12-7577-2012, 2012.

Bao, L., Matsumoto, M., Kubota, T., Sekiguchi, K., Wang, Q., and Sakamoto, K.: Gas/particle partitioning of low-molecular-weight dicarboxylic acids at a suburban site in Saitama, Japan, Atmos. Environ., 47, 546-553, 2012.

Baron, P. A. and Willeke, K.: Aerosol measurement: Principles, techniques, and applications, 2nd ed., John Wiley and Sons, New York, NY, USA, 2001.

Bertram, T. H., Kimmel, J. R., Crisp, T. A., Ryder, O. S., Yatavelli, R. L. N., Thornton, J. A., Cubison, M. J., Gonin, M., and Worsnop, D. R.: A field-deployable, chemical ionization timeof-flight mass spectrometer, Atmos. Meas. Tech., 4, 1471-1479, doi:10.5194/amt-4-1471-2011, 2011.

Bilde, M. and Pandis, S. N.: Evaporation rates and vapor pressures of individual aerosol species formed in the atmospheric oxidation of $\alpha$ - and $\beta$-pinene, Environ. Sci. Technol., 35, 3344-3349, 2001.

Capouet, M., Muller, J.-F., Ceulemans, K., Compernolle, S., Vereecken, L., and Peeters, J.: Modeling aerosol formation in alpha-pinene photo-oxidation experiments, J. Geophys. Res., 113, D02308, doi:10.1029/2007JD008995, 2008.

Cappa, C. D.: A model of aerosol evaporation kinetics in a thermodenuder, Atmos. Meas. Tech., 3, 579-592, doi:10.5194/amt3-579-2010, 2010. 
Cappa, C. D., Loverjoy, E. R., and Ravishankara, A. R.: Evaporation rates and vapor pressures of the even-numbered $\mathrm{C} 8-\mathrm{C} 18$ monocarboxylic acids, J. Phys. Chem. A, 112, 3959-3964, 2008.

Chacon-Madrid, H. J. and Donahue, N. M.: Fragmentation vs. functionalization: chemical aging and organic aerosol formation, Atmos. Chem. Phys., 11, 10553-10563, doi:10.5194/acp11-10553-2011, 2011.

Chameides, W. L. and Davis, D. D.: Aqueous-phase source of formic acid in clouds, Nature, 304, 427-429, 1983.

Chattopadhyay, S. and Ziemann, P. J.: Vapor pressures of substituted and unsubstituted monocarboxylic and dicarboxylic acids measured using an improved thermal desorption particle beam mass spectrometry method, Aerosol Sci. Technol., 39, 10851100, 2005.

Chebbi, A. and Carlier, P.: Carboxylic acids in the troposphere, occurance, sources, and sinks: A review, Atmos. Environ., 30, 4233-4249, 1996.

Clegg, S. L., Brimblecombe, P., and Wexler, A. S.: A thermodynamic model of the system $\mathrm{H}^{+}-\mathrm{NH}_{4}^{+}-\mathrm{SO}_{4}^{2-}-\mathrm{NO}_{3}^{-}-\mathrm{H}_{2} \mathrm{O}$ at tropospheric temperatures, J. Phys. Chem. A, 102, 2137-2154, 1998.

de Gouw, J. A., Middlebrook, A. M., Warneke, C., Goldan, P. D., Kuster, W. C., Roberts, J. M., Fehsenfeld, F. C., Worsnop, D. R., Canagaratna, M. R., Pszenny, A. A. P., Keene, W. C., Marchewka, M., Bertman, S. B., and Bates, T. S.: Budget of organic carbon in a polluted atmosphere: Results from the new england air quality study in 2002, J. Geophys. Res., 110, D16305, doi:10.1029/2004JD005623, 2005.

DeCarlo, P. F., Kimmel, J. R., Trimborn, A., Northway, M., Jayne, J. T., Aiken, A. C., Gonin, M., Fuhrer, K., Horvath, T., Docherty, K. S., Worsnop, D. R., and Jimenez, J. L.: Field-deployable, high-resolution, time-of-flight aerosol mass spectrometer, Anal. Chem., 78, 8281-8289, 2006.

Donahue, N. M., Robinson, A. L., Stanier, C. O., and Pandis, S. N.: Coupled partitioning, dilution and chemical aging of semivolatile organics, Environ. Sci. Technol., 40, 2635-2643, 2006.

Donahue, N. M., Epstein, S. A., Pandis, S. N., and Robinson, A. L.: A two-dimensional volatility basis set: 1. organic-aerosol mixing thermodynamics, Atmos. Chem. Phys., 11, 3303-3318, doi:10.5194/acp-11-3303-2011, 2011.

Donahue, N. M., Kroll, J. H., Pandis, S. N., and Robinson, A. L.: A two-dimensional volatility basis set - Part 2: Diagnostics of organic-aerosol evolution, Atmos. Chem. Phys., 12, 615-634, doi:10.5194/acp-12-615-2012, 2012a.

Donahue, N. M., Robinson, A. L., Trump, E. R., Riipinen, I., and Kroll, J. H.: Volatility and aging of atmopsheric organic aerosol, Topics in Current Chemistry, 339, 97-143, doi:10.1007/1128_2012_1355, 2012b.

Durham, J. L. and Stockburger, L.: Nitric acid-air diffusion coefficient: experimental determination, Atmos. Environ., 20, 559563, 1986

E-AIM: Extended aerosol inorganic model II, available at: http:// www.aim.env.uea.ac.uk/aim/aim.php, 2012.

Epstein, S. A., Riipinen, I., and Donahue, N. M.: A semiempirical correlation between enthalpy of vaporization and saturation concentration for organic aerosol, Environ. Sci. Technol., 44, 743748, 2010

Ervens, B., Turpin, B. J., and Weber, R. J.: Secondary organic aerosol formation in cloud droplets and aqueous parti- cles (aqSOA): a review of laboratory, field and model studies, Atmos. Chem. Phys., 11, 11069-11102, doi:10.5194/acp-1111069-2011, 2011.

Fisseha, R., Dommen, J., Gaeggeler, K., Weingartner, E., Samburova, V., Kalberer, M., and Baltensperger, U.: Online gas and aerosol measurement of water soluble carboxylic acids in Zurich, J. Geophys. Res., 111, D12316, doi:10.1029/2005JD006782, 2006.

Fry, J. L., Draper, D. C., Zarzana, K. J., Campuzano-Jost, P., Day, D. A., Jimenez, J. L., Brown, S. S., Cohen, R. C., Kaser, L., Hansel, A., Cappellin, L., Karl, T., Hodzic Roux, A., Turnipseed, A., Cantrell, C., Lefer, B. L., and Grossberg, N.: Observations of gas- and aerosol-phase organic nitrates at BEACHON-RoMBAS 2011, Atmos. Chem. Phys., 13, 8585-8605, doi:10.5194/acp-138585-2013, 2013.

Furukawa, T. and Takahashi, Y.: Oxalate metal complexes in aerosol particles: implications for the hygroscopicity of oxalatecontaining particles, Atmos. Chem. Phys., 11, 4289-4301, doi:10.5194/acp-11-4289-2011, 2011.

Hallquist, M., Wenger, J. C., Baltensperger, U., Rudich, Y., Simpson, D., Claeys, M., Dommen, J., Donahue, N. M., George, C., Goldstein, A. H., Hamilton, J. F., Herrmann, H., Hoffmann, T., Iinuma, Y., Jang, M., Jenkin, M. E., Jimenez, J. L., Kiendler-Scharr, A., Maenhaut, W., McFiggans, G., Mentel, Th. F., Monod, A., Prévôt, A. S. H., Seinfeld, J. H., Surratt, J. D., Szmigielski, R., and Wildt, J.: The formation, properties and impact of secondary organic aerosol: current and emerging issues, Atmos. Chem. Phys., 9, 5155-5236, doi:10.5194/acp-9-51552009, 2009.

Heald, C. L., Jacob, D. J., Park, R. J., Russell, L. M., Huebert, B. J., Seinfeld, J. H., Liao, H., and Weber, R. J.: A large organic aerosol source in the free troposphere missing from current Models, Geophys. Res. Lett., 32, L18809, doi:10.1029/2005GL023831, 2005.

Heald, C. L., Coe, H., Jimenez, J. L., Weber, R. J., Bahreini, R., Middlebrook, A. M., Russell, L. M., Jolleys, M., Fu, T.-M., Allan, J. D., Bower, K. N., Capes, G., Crosier, J., Morgan, W. T., Robinson, N. H., Williams, P. I., Cubison, M. J., DeCarlo, P. F., and Dunlea, E. J.: Exploring the vertical profile of atmospheric organic aerosol: comparing 17 aircraft field campaigns with a global model, Atmos. Chem. Phys., 11, 12673-12696, doi:10.5194/acp-11-12673-2011, 2011.

Hennigan, C. J., Bergin, M. H., Russell, A. G., Nenes, A., and Weber, R. J.: Gas/particle partitioning of water-soluble organic aerosol in Atlanta, Atmos. Chem. Phys., 9, 3613-3628, doi:10.5194/acp-9-3613-2009, 2009.

Hilal, S. H., Karickhoff, S. W., and Carreira, L. A.: Prediction of the vapor pressure boiling point, heat of vaporization and diffusion coefficient of organic compounds, QSAR Comb. Sci., 22, 565574, 2003.

Hodzic, A., Jimenez, J. L., Madronich, S., Canagaratna, M. R., DeCarlo, P. F., Kleinman, L., and Fast, J.: Modeling organic aerosols in a megacity: potential contribution of semi-volatile and intermediate volatility primary organic compounds to secondary organic aerosol formation, Atmos. Chem. Phys., 10, 5491-5514, doi:10.5194/acp-10-5491-2010, 2010.

Holzinger, R., Goldstein, A. H., Hayes, P. L., Jimenez, J. L., and Timkovsky, J.: Chemical evolution of organic aerosol in Los Angeles during the CalNex 2010 study, Atmos. Chem. Phys. 
Discuss., 13, 12867-12911, doi:10.5194/acpd-13-12867-2013, 2013.

Jaoui, M. and Kamens, R. M.: Gaseous and particulate oxidation products analysis of a mixture of $\alpha$-pinene $+\beta$-pinene $/ \mathrm{O}_{3} /$ air in the absence of light and $\alpha$-pinene $+\beta$-pinene/ $/ \mathrm{NO}_{\mathrm{x}} /$ air in the presence of natural sunlight, J. Atmos. Chem., 44, 259-297, 2003.

Jimenez, J. L., Canagaratna, M. R., Donahue, N. M., Prevot, A. S. H., Zhang, Q., Kroll, J. H., DeCarlo, P. F., Allan, J. D., Coe, H., Ng, N. L., Aiken, A. C., Docherty, K. S., Ulbrich, I. M., Grieshop, A. P., Robinson, A. L., Duplissy, J., Smith, J. D., Wilson, K. R., Lanz, V. A., Hueglin, C., Sun, Y. L., Tian, J., Laaksonen, A., Raatikainen, T., Rautiainen, J., Vaattovaara, P., Ehn, M., Kulmala, M., Tomlinson, J. M., Collins, D. R., Cubison, M. J., Dunlea, E. J., Huffman, J. A., Onasch, T. B., Alfarra, M. R., Williams, P. I., Bower, K., Kondo, Y., Schneider, J., Drewnick, F., Borrmann, S., Weimer, S., Demerjian, K., Salcedo, D., Cottrell, L., Griffin, R., Takami, A., Miyoshi, T., Hatakeyama, S., Shimono, A., Sun, J. Y., Zhang, Y. M., Dzepina, K., Kimmel, J. R., Sueper, D., Jayne, J. T., Herndon, S. C., Trimborn, A. M., Williams, L. R., Wood, E. C., Middlebrook, A. M., Kolb, C. E., Baltensperger, U., and Worsnop, D. R.: Evolution of organic aerosols in the atmosphere, Science, 326, 1525-1529, 2009.

Kalberer, M., Paulsen, D., Sax, M., Steinbacher, M., Dommen, J., Prevot, A. S. H., Fisseha, R., Weingartner, E., Frankevich, V., Zenobi, R., and Baltensperger, U.: Identification of polymers as major components of atmospheric organic aerosols, Science, 303, 1659-1662, 2004.

Kavouras, I. G., Mihalopoulos, N., and Stephanou, E. G.: Formation of atmospheric particles from organic acids produced by forests, Nature, 395, 683-686, 1997.

Kawamura, K., Ng, L. L., and Kaplan, I. R.: Determination of organic acids (C1-C10) in the atmosphere, motor exhausts, and engine oils, Environ. Sci. Technol., 19, 1082-1086, 1985.

Keene, W. C., Pszenny, A. A. P., Maben, J. R., Stevenson, E., and Wall, A.: Closure evaluation of size-resolved aerosol $\mathrm{pH}$ in the new england coastal atmosphere during summer, J. Geophys. Res., 109, D23307, doi:10.1029/2004JD004801, 2004.

Kim, S., Karl, T., Guenther, A., Tyndall, G., Orlando, J., Harley, P., Rasmussen, R., and Apel, E.: Emissions and ambient distributions of Biogenic Volatile Organic Compounds (BVOC) in a ponderosa pine ecosystem: interpretation of PTR-MS mass spectra, Atmos. Chem. Phys., 10, 1759-1771, doi:10.5194/acp-101759-2010, 2010.

Linstrom, P. J. and Mallard, W. G. (Eds.): "Entropy and heat capacity data" in NIST chemistry webbook, NIST standard reference database number 69, National Institute of Standards and Technology, Gaithersburg, MD, 2005.

Liu, J., Zhang, X., Parker, E. T., Veres, P. R., Roberts, J. M., de Gouw, J. A., Hayes, P. L., Jimenez, J. L., Murphy, J. G., Ellis, R. A., Huey, G. L., and Weber, R. J.: On the gas-particle partitioning of soluble organic aerosol in two urban atmospheres with contrasting emissions: 2. gas and particle phase formic acid, J. Geophys. Res., 117, D00V21, doi:10.1029/2012JD017912, 2012.

Matsunaga, S. N., Kato, S., Yoshino, A., Greenberg, J. P., Kajii, Y., and Guenther, A. B.: Gas-aerosol partitioning of semi volatile carbonyls in polluted atmosphere in Hachioji, Tokyo, Geophys. Res. Lett., 32, L11805, doi:10.1029/2004GL021893, 2005.
Mohr, C., Lopez-Hilfiker, F. D., Zotter, P., Prevot, A. S. H., Xu, L., Ng, L. N., Herndon, S. C., Williams, L. R., Franklin, J. P., Zahniser, M. S., Worsnop, D. R., Knighton, W. B., Aiken, A. C., Gorkowski, K. J., Dubey, M. K., Allan, J. D., and Thornton, J. A.: Contribution of nitrated phenols to woob burning brown carbon light absorption in Detling, United Kingdom during winter time, Environ. Sci. Technol., 47, 6316-6324, 2013.

Moldoveanu, S. C.: Pyrolysis of carboxylic acids, in: Pyrolysis of organic molecules with applications to health and environmental issues, edited by: Moldoveanu, S. C., 471-526, Elsevier, Amsterdam, 2010.

Müller, L., Reinnig, M.-C., Naumann, K. H., Saathoff, H., Mentel, T. F., Donahue, N. M., and Hoffmann, T.: Formation of 3-methyl1,2,3-butanetricarboxylic acid via gas phase oxidation of pinonic acid - a mass spectrometric study of SOA aging, Atmos. Chem. Phys., 12, 1483-1496, doi:10.5194/acp-12-1483-2012, 2012.

Murphy, D. M., Cziczo, D. J., Froyd, K. D., Hudson, P. K., Matthew, B. M., Middlebrook, A. M., Peltier, R. E., Sullivan, A., Thomson, D. S., and Weber, R. J.: Single-particle mass spectrometry of tropospheric aerosol particles, J. Geophys. Res., 111, D23S32, doi:10.1029/2006JD007340, 2006.

Myrdal, P. B. and Yalkowsky, S. H.: Estimating pure component vapor pressures of complex organic molecules, Ind. Eng. Chem. Res., 36, 2494-2499, 1997.

Nannoolal, Y., Rarey, J., and Ramjugernath, D.: Estimation of pure component properties Part 3. estimation of the vapor pressure of non-electrolyte organic compounds via group contributions and group interactions, Fluid Phase Equilibria, 269, 117-133, 2008.

Ng, N. L., Canagaratna, M. R., Jimenez, J. L., Chhabra, P. S., Seinfeld, J. H., and Worsnop, D. R.: Changes in organic aerosol composition with aging inferred from aerosol mass spectra, Atmos. Chem. Phys., 11, 6465-6474, doi:10.5194/acp-11-64652011, 2011.

Odum, J. R., Hoffmann, T., Bowman, F., Collins, D., Flagan, R. C., and Seinfeld, J. H.: Gas/particle partitioning and secondary organic aerosol yields, Environ. Sci. Technol., 30, 2580-2585, 1996.

Pankow, J. F.: An absorption Mmodel of gas/particle partitioning of organic compounds in the atmosphere, Atmos. Environ., 28, 185-188, 1994.

Pankow, J. F. and Asher, W. E.: SIMPOL.1: a simple group contribution method for predicting vapor pressures and enthalpies of vaporization of multifunctional organic compounds, Atmos. Chem. Phys., 8, 2773-2796, doi:10.5194/acp-8-27732008, 2008.

Paulot, F., Wunch, D., Crounse, J. D., Toon, G. C., Millet, D. B., DeCarlo, P. F., Vigouroux, C., Deutscher, N. M., González Abad, G., Notholt, J., Warneke, T., Hannigan, J. W., Warneke, C., de Gouw, J. A., Dunlea, E. J., De Mazière, M., Griffith, D. W. T., Bernath, P., Jimenez, J. L., and Wennberg, P. O.: Importance of secondary sources in the atmospheric budgets of formic and acetic acids, Atmos. Chem. Phys., 11, 1989-2013, doi:10.5194/acp-11-1989-2011, 2011.

Perraud, V., Burns, E. A., Ezell, M., Johnson, S. N., Yu, Y., Alexander, M. L., Zelenyuk, A., Imre, D., Chang, W. L., Dabdub, D., Pankow, J. F., and Finlayson-Pitts, B. J.: Nonequilibrium atmospheric secondary organic aerosol formation and growth, P. Natl. Acad. Sci., 109, 2836-2841, 2012. 
Poling, B. E., Prausnitz, J. M., and O'Connell, J. P.: The properties of gases and liquids, 5th ed., McGraw-Hill, New York, NY, 2001.

Reaxys database: Reed Elsevier Properties SA, available at: https: //www.reaxys.com/reaxys/secured/start.do, last access: 2012.

Renbaum-Wolff, L., Grayson, J. W., Bateman, A. P., Kuwata, M., Sellier, M., Murry, B. J., Shilling, J. E., Martin, S. T., and Bertram, A. K.: Viscosity of a-pinene secondary organic material and implications for particle growth and reactivity, P. Natl. Acad. Sci., 110, 8014-8019, 2013.

Robinson, A. L., Donahue, N. M., Shrivastava, M. K., Weitkamp, E. A., Sage, A. M., Grieshop, A. P., lane, T. E., Pierce, J. R., and Pandis, S. P.: Rethinking organic aerosols: semivolatile emissions and photochemical aging, Science, 315, 1259-1262, 2007.

Rogge, W. F., Hildemann, L. M., Mazurek, M. A., and Cass, G. R.: Sources of fine organic aerosol. 1. Charbroilers and meat cooking operations, Environ. Sci. Technol., 25, 1112-1125, 1991.

Rogge, W. F., Hildemann, L. M., Mazurek, M. A., and Cass, G. R.: Sources of fine organic aerosol. 4. Particulate abrasion products from leaf surfaces of urban plants, Environ. Sci. Technol., 27, 2700-2711, 1993a.

Rogge, W. F., Mazurek, M. A., Hildemann, L. M., and Cass, G. R.: Quantification of urban orgnaic aerosols at a molecular level: Identification, abundance and seasonal variation, Atmos. Environ., 27, 1309-1330, 1993b.

Saleh, R., Donahue, N. M., and Robinson, A. L.: Time scales for gas-particle partitioning equilibration of secondary organic aerosol formed from alpha-pinene ozonolysis, Environ. Sci. Technol., 47, 5588-5594, 2013.

Salo, K., Jonsson, A. M., Andersson, P. U., and Hallquist, M.: Aerosol volatility and enthalpy of sublimation of carboxylic acids, J. Phys. Chem. A, 114, 4586-4594, 2010.

Shiraiwa, M. and Seinfeld, J. H.: Equilibration timescale of atmospheric secondary organic aerosol partitioning, Geophys. Res. Lett., 39, L24801, doi:10.1029/2012GL054008, 2012.

Shiraiwa, M., Zuend, A., Bertram, A. K., and Seinfeld, J. H.: Gasparticle partitioning of atmospheric aerosols: interplay of physical state, non-ideal mixing and morphology, Phys. Chem. Chem. Phys., 15, 11441-11453, 2013.

Sommariva, R., de Gouw, J. A., Trainer, M., Atlas, E., Goldan, P. D., Kuster, W. C., Warneke, C., and Fehsenfeld, F. C.: Emissions and photochemistry of oxygenated VOCs in urban plumes in the Northeastern United States, Atmos. Chem. Phys., 11, 70817096, doi:10.5194/acp-11-7081-2011, 2011.

Spracklen, D. V., Jimenez, J. L., Carslaw, K. S., Worsnop, D. R., Evans, M. J., Mann, G. W., Zhang, Q., Canagaratna, M. R., Allan, J., Coe, H., McFiggans, G., Rap, A., and Forster, P.: Aerosol mass spectrometer constraint on the global secondary organic aerosol budget, Atmos. Chem. Phys., 11, 12109-12136, doi:10.5194/acp-11-12109-2011, 2011.

Szmigielski, R., Surratt, J. D., Gomez-Gonzalez, Y., Van der Verken, P., Kourtchev, I., Vermeylen, R., Blockhuys, F., Jaoui, M., Kleindienst, T. E., Lewandowski, M., Offenberg, J. H., Edney, E. O., Seinfeld, J. H., Maenhaut, W., and Claeya, M.: 3Methyl-1,2,3-Butanetricarboxylic acid: An atmospheric tracer for terpene secondary organic aerosol, Geophys. Res. Lett., 34, L24811, doi:10.1029/2007GL031338, 2007.

Terzi, E. and Samara, C.: Gas-particle partitioning of polycyclic aromatic hydrocarbons in urban, adjacent coastal, and continen- tal background sites of western Greece, Environ. Sci. Technol., 38, 4973-4978, 2004

UManSysProp: University of Manchester multiphase system online property prediction, available at: http://ratty.cas.manchester.ac. uk/informatics/, last access: July 2012.

Vaden, T. D., Imre, D., Beranek, J., Shrivastava, M. K., and Zelenyuk, A.: Evaporation kinetics and phase of laboratory and ambient secondary organic aerosol, P. Natl. Acad. Sci., 108, 21902195, 2011.

Veres, P., Roberts, J. M., Warneke, C., Welsh-Bon, D., Zahniser, M., Herndon, S., Fall, R., and De Gouw, J. A.: Development of negative-ion proton-transfer chemical-ionization mass spectrometry (NI-PT-CIMS) for the measurement of gas-phase organic acids in the atmosphere, Int. J. Mass Spectrom., 274, 4855,2008

Veres, P. R., Roberts, J. M., Cochran, A. K., Gilman, J. B., Kuster, W. C., Holloway, J. S., Graus, M., Flynn, J., Lefer, B. L., Warneke, C., and de Gouw, J. A.: Evidence of rapid production of organic acids in an urban air mass, Geophys. Res. Lett., 38 , L17807, doi:10.1029/2011GL048420, 2011.

Virtanen, A., Jotsensaari, J., Koop, T., Kannosto, J., Yli-Pirila, P., Leskinen, J., Makela, J. M., Holopainen, J. K., Poschl, U., Kulmala, M., Worsnop, D. R., and Laaksonen, A.: An amorphous solid state of biogenic secondary orgnaic aerosol particles, Nature, 467, 824-827, 2010.

Vogel, A. L., Äijälä, M., Brüggemann, M., Ehn, M., Junninen, H., Petäjä, T., Worsnop, D. R., Kulmala, M., Williams, J., and Hoffmann, T.: Online atmospheric pressure chemical ionization ion trap mass spectrometry (APCI-IT-MSn) for measuring organic acids in concentrated bulk aerosol - a laboratory and field study, Atmos. Meas. Tech., 6, 431-443, doi:10.5194/amt-6-431-2013, 2013.

Volkamer, R., Jimenez, J. L., Martini, F. S., Dzepina, K., Zhang, Q., Salcedo, D., Molina, L. T., Worsnop, D. R., and Molina, M. J.: Secondary organic aerosol formation from anthropogenic air pollution: Rapid and higher than expected, Geophys. Res. Lett., 33, L17811, doi:10.1029/2006GL026899, 2006.

Williams, B. J., Goldstein, A. H., Millet, D. B., Holzinger, R., Kreisberg, N. M., Hering, S. V., Allan, J. D., Worsnop, D. R., Jimenez, J. L., and White, A. B.: Chemical speciation of organic aerosol during ICARTT 2004: Results from in-situ measurements, J. Geophys. Res., 112, D10S26, doi:10.1029/2006JD007601, 2007.

Williams, B. J., Goldstein, A. H., Kreisberg, N. M., and Hering, S. V.: In situ measurements of gas/particle-phase transitions for atmospheric semivolatile organic compounds, P. Natl. Acad. Sci., 107, 6676-6681, doi:10.1073/pnas.0911858107, 2010.

Xing, L., Fu, T.-M., Cao, J. J., Lee, S. C., Wang, G. H., Ho, K. F., Cheng, M.-C., You, C.-F., and Wang, T. J.: Seasonal and spatial variability of the $\mathrm{OM} / \mathrm{OC}$ mass ratios and high regional correlation between oxalic acid and zinc in Chinese urban organic aerosols, Atmos. Chem. Phys., 13, 4307-4318, doi:10.5194/acp13-4307-2013, 2013.

Yasmeen, F., Szmigielski, R., Vermeylen, R., Gomez-Gonzalez, Y., Surratt, J. D., Chan, A. W. H., Seinfeld, J. H., Maenhaut, W., and Claeya, M.: Mass spectrometric characterization of isomeric terpenoic acids from the oxidation of $\alpha$-pinene, $\beta$-pinene, $d$ limonene, and $\Delta^{3}$-carene in fine forest aerosol, J. Mass Spectrom., 46, 425-442, 2011. 
Yatavelli, R. L. N. and Thornton, J. A.: Particulate organic matter detection using a micro-orifice volatilization impactor coupled to a chemical ionization mass spectrometer (MOVI-CIMS), Aerosol Sci. Technol., 44, 61-74, 2010.

Yatavelli, R. L. N., Hilfiker, F. L., Wargo, J. D., Kimmel, J. R., Cubison, M. J., Bertram, T. H., Jimenez, J. L., Gonin, M., Worsnop, D. R., and Thornton, J. A.: A chemical ionization highresolution time-of-flight mass spectrometer coupled to a micro orifice volatilization impactor (MOVI-HRToF-CIMS) for analysis of gas and particle-phase organic species, Aerosol Sci. Technol., 46, 1313-1327, 2012.

Zhang, Q., Jimenez, J. L., Canagaratna, M. R., Allan, J. D., Coe, H., Ulbrich, I., Alfarra, M. R., Takami, A., Middlebrook, A. M., Sun, Y. L., Dzepina, K., Dunlea, E., Docherty, K., DeCarlo, P. F., Salcedo, D., Onasch, T., Jayne, J. T., Miyoshi, T., Shimono, A., Hatakeyama, S., Takegawa, N., Kondo, Y., Schneider, J., Drewnick, F., Borrmann, S., Weimer, S., Demerjian, K., Williams, P., Bower, K., Bahreini, R., Cottrell, L., Griffin, R. J., Rautiainen, J., Sun, J. Y., Zhang, Y. M., and Worsnop, D. R.: Ubiquity and dominance of oxygenated species in organic aerosols in anthropogenically-influenced northern hemisphere midlatitudes, Geophys. Res. Lett., 34, L13801, doi:10.1029/2007GL029979, 2007.
Zhang, X., Liu, J., Parker, E. T., Hayes, P. L., Jimenez, J. L., de Gouw, J. A., Flynn, J. H., Grossberg, N., Lefer, B. L., and Weber, R. J.: On the gas-particle partitioning of soluble organic aerosol in two urban atmospheres with contrasting emissions: 1. Bulk water-soluble organic carbon, J. Geophys. Res., 117, D00V16, doi:10.1029/2012JD017908, 2012.

Zhao, Y., Kreisberg, N. M., Worton, D. R., Isaacman, G., Weber, R. J., Liu, S., Day, D. D., Russell, L. M., Markovic, M. Z., Vandenboer, T. C., Murphy, J. G., Hering, S. V., and Goldstein, A. H.: Insights into secondary organic aerosol formation mechanisms from measured gas/particle partitioning of specific organic tracer compounds, Environ. Sci. Technol., 47, 3781-3787, 2013. 